\title{
圧縮を受ける船体構造部分の挫屈 並に圧壞强度の研究
}

\author{
正員 工学士 吉 識 雅 夫
}

第 1 章 総

論

\section{$\S 1 \cdot 1$ 緒}

言

船体緃強度の計画に当つては, 先ず外力としての曲げモーメントを求め, 梁理諭に従つて縦強度材に生ずる応 力を計算し，その值を一定の適当なる許容㐫力以下になる様に設計せられるのを普通とする。然るに許容㐫力の 決定の基礎として考えられるものは材料の引張り強さ, 降伏点, 渡労限等があるが, 船体の如く重量軽隇の必要 上船体構成材料の寸法を極減し，薄板とその防撓材とを以つて組立てられた構造に於ては生維による挫屈に起因

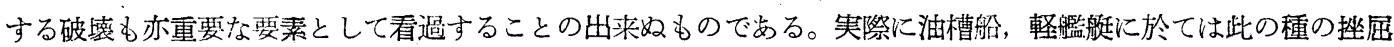
による破損が，他種のるのに比し最も起り易いことは諸種の実例(1)の示す所である。

然るに挫屈による破損に於ては，材質が一定であつても，一定の応力で破䘫が起るとは限らず，構造寸法，形 状等によりその值に大小を生ずることは他種の破壊とは趣を異にしている。而して防撓薄板構造物の王縮によ゙る 挫屈破塄強庋に関しては, 彷来実用に供し得る簡単な設計方式についての研究に火けて居り, 双実験的研究に於 ても繿船に傎用せられる軟鋼材につき，実際の使用状態に適合した条件の下に実施せられたものに火けていた。 その為，压縮を受ける鏳造部分の設䛅炕当つては，四辺支持或は四辺固定の理想的条件の下に計算せられた矩形 板の挫屈限界応力を基にして，外力より計算せられた圧縮忍力が此の挫屈限界芯力を超え双程度を目標として， 計画せられるのを普通とした。

而して挫屈限界の計算值と実際の場合に於行る挫屈限界值との関聯性, 特に初期撓みの影響に関する検討, 又 防撓材で芰えられた場合に採るべき周辺条件の問題, 並に防撓構造に於什る板の挫屈後の特性, 特に板の挫屈限 界と防撓構造の圧壊荷重との関係等の諸点を明確にせね蚆挫屈限界点を基礎とする設計法も十分なものというこ とは出来ない。

従つて軽構造の繿船に於ては, 此の種防撓薄板構造の圧縮による挫屈強度並に圧壊強度の䂙究は, 最も緊要な るものといらことが出来る。

本論文は，以上の栚な現状に対処し，船体構造部分の压縮破壊に対する設計計画の資粼を得る為，船体用軟鋼 板と型鋼とを以つて構成せられた簡単なる構造模型につき, 王縮荷重を加え, 防撓薄板構造物の压縮による挫屈 限度，並に挫屈に起因する压壊绌度につき，研究せんとするものである。

\section{$\S 1 \cdot 2$ 防澆薄板構造物が圧縮荷重を受けた場合に於ける圧壊に至る迄の経過}

防撓材を有する薄板構造物が圧縮荷重を受けるとき, 荷重小なる間は荷重方向の压縮昰は荷重に此例し, 構造 物の任縮剛性に逆比例する。荷重が漸次増大し防撓材間の薄板の挫屈限界附近に達すると, 板には板面に直角な 撓み（以下横撓みと称す）が生ずると共に圧縮歪も急激に增大し，压縮沁力一圧縮歪の曲線はその傾斜を変更し 有效止縮剛性の減少することを示す。此の際防撓材には未だ横撓みの発生は認められないのが普通である。但し 板厚が防撓材寸法に比し厚い場合には板に横撓みが生ずると共に防撓材にも同時に相当の横撓及を生じ, 防撓材 る挫屈を生ずることもあり得る。併し普通に艦船に於て使用せられる程度の寸法に於ては防撓材が板と同時に挫 屈を生ずることは先ずないものと考㝋てよい。

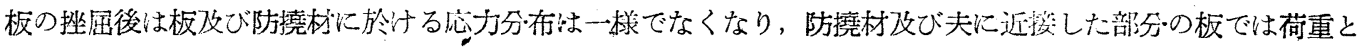

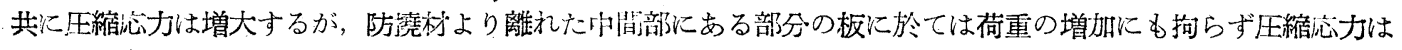

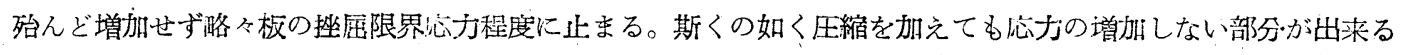
ので, 全体としては縮み量に比し荷重の橧抈量少く, 換言すれば荷重の増加に比し縮み量圷大となり压縮に対す る㓮性が減少することになる。 
斯様な状態で更に荷重を增加して行くと防撓材も挫屈を生じ，荷重一縮み量曲線の傾斜は漸次減少し遂に最大 荷重に達し圧壊し去るに至る。

以上に記述した如く防撓薄板構造物が圧縮荷重を受けて圧壊する過程に於ては, 薄板の挫屈, 板の挫屈後の有 效岡性の減少，次に防撓材の挫屈の段階を経て最高荷重に至るものである。

\section{$\S 1 \cdot 3$ 圧縮を受ける防撓薄板構造の強度に関する既往の研究概説}

i） 矩形平板の挫屈限界点

圧縮荷重の増大と共に先ず板の挫屈を生ずることは前節に記述した所であるが，矩形平板の挫屈荷重に就いて は, 1891 年 G. H. Bryan(2) により周辺自由支持の場合に就き挫屈限界荷重が求められて以来, 諸種の周辺条 件に対し限界荷重の計算が発表せられている。即ち周辺固定の場合に対しては, 妹沢克惟 ${ }^{(3)}$, 山名正夫 ${ }^{(4)}, \mathrm{G} . \mathrm{I}$. Taylor(5), H.L. Cox ${ }^{(6)}$, O.H. Faxen(7), 井口鹿象(8), J.L. Maulbetch ${ }^{(9)}$ 等により諸種の解法が試みられ, 荷重辺支持，他辺固定の場合に対しては S. Timoshenko(10)，妹沢克惟 ${ }^{(3)}$, H.L. Cox ${ }^{(6)}$ 等の解法がある。

一方実験的研究としては周辺自由支持に対して L. Schuman \& G. Back(11)，横尾孝義(12) の研究が発表せ られて居り，H.L. $\operatorname{Cox}^{(6)(13)}$ 及ひび R. Lahde，H. Wagner(14) は荷重に平行な辺を固定した場合並に防撓材で 支持した場合の結果を示している。併し H. L. Cox(13) を除き何れも試験用材質はデュラルミン其他航空機用材 料を主とし，艦船用軟鋼に就いての結果に火けている。但し軟鋼て関する実験としては J. Montgomerie(15)の 実験があるが，之は荷重に平行な辺は自由であり防撓樍造に対しては適用し得ないるのと考えられる。

而して以上の実験厄於て挫屈限界点関する実験結果の詳細を発表したものはなく，L. Schuman， G. Back の実験では G. H. Bryan の計算値より低く，H. L. Cox ${ }^{(6)}$ は試験片1ケを除き計算值と一致したとの記載が あるだけである。又 H. L. Cox (13) の防撓材で支えられた試験片では四周支持として計算した挫屈限界荷重 26 ton に対し，実験值 29 ton で略々一致した結果を示しているのがある。

以上の如く挫屈限界点に関しては実験值の認むべきものはなく, 特に周辺支持の場合に対しては理論による計 算値をその㦎設計に使用して差支えないか否かの判定資料がない状態である。

ii）平板の挫屈後の有效圧縮剛性並に圧壊を生ずる最大荷重

板の挫屈後王縮に対する剛性の減少することは既述の通りであるが, 此の問題に就いては, G. Schnadel(16), Th. von Kármán, E.E. Sechler, L.H. Donnell(17), H. L. Cox ${ }^{(6)}$, 山本峰雄, 近藤一夫(18), S. Timoshenko(19)，K. Marguerre(20)，K. Marguerre，E. Treff $z^{(21)}$ 等の理論的研究がある。その有效岡性の大 いさは周辺条件により異り，又周縁芯力の大いさでも異るが，大体挫屈直後に於ては有効岡性は挫屈前の 1/3〜 $1 / 2$ 程度の值を示している。佮有効剛性の值は板の長幅比によつても左右せられることは明かであるが数值計算 の行われているものは, 何れも正方形板の場合のみである。一方実験的研究としては前項に記載の諸実験があり， Cox ${ }^{(6)}$ の実験，Lahde，Wagner，の実験は理論值と大略一致したことが報告せられている。

次に板の耐光得る最大荷重については, 最大荷重を決める条件が著者によつて異り, 且理論の近似度, 解析方 法の差異等によりその結果も区々である。最大荷重決定の条件としては周緑応力が材料の降伏点応力に達した場 合をとるもの (Th. von Kármán), 周縁歪が或る一定值に達した場合をとるもの (H. L. Cox), 最大主忘力 が一定値になつた時をとるもの (山本, 近藤), 剪断流力の最大值により決めるもの (S. Timoshenke) 等の諸 種類がある。大体に於て Cox, Lahde, Wagner の周辺固定の実験は, Cox, Marguerre 等の理論值に略々 一致する様であり，周辺支持の埸合は Kármán の式に倸数を調整すれば Schuman，Back の実験と相当に一 致することが報ぜられている。Kármán の式は比較的簡単な式であるが, 幅の影響を含まない点が多少実験值に 一致しない憾みがある。

iii）板は防撓材によつて弾性的に固定せられて防撓材と共汇挫屈する場合

此の問題については S. Timoshenko(22) がエネルギー法によつて縦方向に防撓材が在る場合，改び横方向に 防撓材の在る場合につき挫屈限界点の計算を行つている。Timoshenko の解は板の周辺は支持としている。そ の後 L. Rendulic(23)，J. Miles(24) は板の両側に防撓材のある場合につき，又 E. Chwalla(25) は板の両側は 支持で中央に縱防撓材のある場合につき，R. Barbré(26) は板の両側は支持又は固定で縱防撓材 1 本又は 2 本の 場合, 横防撓材 1 本又は 2 本ある場合につき, 防撓材位置に於ける板の撓みにより生ずる剪断力; 曲げモーメン トの分布が夫々防撓材の曲げモーメント，搌りモーメミトに釣合うものとして解析を行つている。

夫等の結果によれば防撓材の曲於剛性相当大であり且長幅此小なる場合は防撓材闕の板の挫屈が先ず現れ，長 
さ大なる場合は全体としての挫屈が現れる。両側を防撓材で支持した場合には此の全体的の挫屈は Euler の挫 屈に一致する。又板厚に比し防撓材の曲げ岡性小になるに従つて板の挫屈は別箇に現れず，板と防撓材が同時に 挫屈を生ずる。而して本実験の模型寸法 (特別のものを除く), 従つて艦船に使用せられる程度の構造寸法では, 此の種の挫屈は先ず現れないことを示している。

iv） 压縮を受ける薄板防撓構造物の最大荷重

前項に記載した通り板と防撓材とが同時に挫屈を生ずる樣な構造は此較的厚い板に弱い防撓材を附したもので あり, 構造重量軽減の見地からは不向の構造である。従つて重量軽減を主眼とした薄板構造では主として以下に 記述する如く板が先ず挫屈し，その後に防撓材と挫屈後の板とが圧壊することになる。故に此の型式の圧壊に対 する最大荷重の算定法が最る重要な問題となる。

扱て此の梯な場合の最大荷重を決定する条件としては次の様なものが考光られている。即ち防撓材の Euler 挫屈, 防撓材の㨝り挫屈, 防撓材の自由辺の解波挫屈 (局部的挫屈), 防撓材取付鋲間に於汁る板の挫屈（鋲間挫 屈と称す), 防撓材又は板の応力が材料の圧縮に対する極限強さに違すること等の諸種の条件である。

之等の内防撓材の据り，自由辺の物波挫屈等飞より最大值の決定せられることは E.E. Lundquist \& C.M. Fligg(27)，倉西正嗣(28) 等により論ぜられている。主として長さの短い場合に起る現象である。

次の鋲間挫屈は W. L. Howland( ${ }^{(29)}$, A. Kromm(30) 等によつて研究せられたが, 此の鋲間挫屈の発生は航 空機構造の如く鋲心距が広く，心距が鋲径の大約 10 倍程度以上* の場合に生ずるもので，船体構造の如き鋲心 距では先ず生じないものと考えてよい。㣚鋲間挫屈を生じても最大荷重に達しない場合に於ける䤱間挫屈後の状

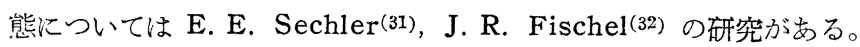

板又は防撓材の王樎灾力が村料により定まつた一定の応力（圧綟強さ又は降伏点等）に達することによつて防 掊構造の最大荷重が決定されることもあり得ることは H. L. Cox (33), E. E. Sechler(31) 等によつて考えられた が，一方防撓構造の最大荷重は板の抗正力で洪められた值よりも高くなるという説も呾えられている。(H. B. Dickinson \& J. R. Fischel( $\left.{ }^{(34)}\right)$ 板又は防撓材忍力の一定応力到達によつて最大荷重が沠定されるか否かはそ の構造並に寸法特に長さとの関聯によつて左右せられるべきものである。

防撓材の Euler 挫屈に起因する圧壊に関しては，G. F. Wallace(35), O.S. Heck \& H. Ebner(36), E. E. Sechler(31), E. E. Lundquist \& C. M. Fligg(27), N. J. Hoff(37), E. R. Reff(38), H. L. Cox ${ }^{(39)}$ 等により 論ぜられている。之等の論文で論ぜられた最大荷重の算定法はその細部に於ては多小異るが，根本方針に就いて は大同小異で, その要旨は大的次の通りである。即ち防撓材間の薄板は挫屈後その有効剛性を減じ所謂有効幅の 現象を呈す。それで先ず挫屈後の有效幅を決定する必要があるが，夫には von Kármán, Cox, Marguerre 其他何れかの著者の発表にかかる有效幅曲線を基礎として採用する。次に防撓材の挫屈応力を推定又は防撓材の みの压縮実験結果より定める。此の防撓材の挫屈忍力に対して先倸用した有效幅曲線を用いて板の有效幅を算 定する。斯くして求めた板の有效部分と防撓材と両者結合した柱の細長比を求める。此の細長比に対し防撓材の 久の場合の挫屈応力曲線（先に防撓材の挫屈応力を決定せるもの）を用いて板を含む場合の挫屈応力を求める。 此の值は必然的に先に決定した板を含まない場合の挫屈応力とは異る。故に此の後沉求めた挫屈応力に対して有 㸚幅を求め直し, 有効幅を含む防撓材の計算をやり直す。此の様な手段を繰返し, 各回の最初に仮定した応力と 後に得られた値とが変らない様になる迄行う。此の値を防撓材の挫屈応力として採用し, 此の挫屈応力に防撓材 及び板の有効面積の和を乗ずれば防撓構造物の耐光得る最大荷重が得られるとするものである。以上の様に防撓 構造の最大荷重の算定には相当の手数を要し，且有效幅曲線の選定により結果を異にし，又採用すべき防撓材形 状に応じその挫屈応力曲線を必要とするるのである。但し Cox (39) は有效幅曲線を直線で近似し稍々簡単に最大 值を決定することを論じている。併し防撓材の挫屈応力が基になるべきことを論じている点は他の著者と同一で あり，特に実駼值が斯㥞にして求められた計算值より高い值を示すことがあるが，その原因は板の横方向の初期 撓みの存在汇よると論じている点は注意を要する。命，E．H. Mitchell(40) は両側自由の矩形鋼板及び両側に山 形鋼を有する軟鋼板の実験を行い,その結果矩形板及び山形鋼の压壊強度を算定する実験式を，挫屈限度を基にし 夫に補正を行つた形で求めた。防撓構造の場合には夫を構成している個々の部材について実駼式で最大荷重を計 算し，夫等を加算すれば良いことを論じている。板と山形鋼の氐壊強度が相当の差を示す場合加算したるので求 め得るか否かの点には疑問があり, 又両側自由の板の結果を用いる点にも難点があるものと思惟せられる。

* 厳密には鋲心距と板厚の関係で決めるべきである。 


\section{第 2 章 実験方法, 装置並に模型}

\section{$\S 2 \cdot 1$ 模 型 要 目}

区樎を受ける艦船構造部分の計画に対し利用し得る資料を得ることを目的とし，次の実験系列を選定した。

i）周辺支持矩形平板の実験、

板厚 $2 \mathrm{~mm}, 2.9 \mathrm{~mm}, 4 \mathrm{~mm}$ 双び $5 \mathrm{~mm}$ の艦船用軟錀板につき, 長さは $550 \mathrm{~mm}$ で一定とし, 幅は 560 $\mathrm{mm}$ 乃至 $1818 \mathrm{~mm}$ の間に 4 種類に変光従つて長幅比を変えて実験を行つた。合, 同一種類に対し 3 ケ宛総計 47 ケの試験片を製作し実験を行つた。（表 1 参照）

ii）周辺に防撓材を有する防撓矩形平板の実験。
A. 系統 6 種 12 方
幅/厚一定, 長さ一定とす。
B 系統 4 種 8 ケ
長さ, 幅一定, 厚さ変化す。
C 系統 7 種 14 ケ
幅, 厚さ一定, 長さ変化す。
D 系統 2 種 4 ケ
A, C 系統の補足的のもの。

A-IV 系統 5 種10ケ

A-IV 系統 2 種 4 ケ $\}$

$\{$ 上下, 左右山形銅取付时板の寸法を変化す。

C-II 系統 3 種 61

上下，左右山形金闭取付肘鿆の寸法，

$\mathrm{J}$ 系統 4 種 8 ケ

並に上下山形銅寸法変化。

$\mathrm{K}$ 系統 4 種 8 ケ

山形鋼以外の型鋼を用5。

上下, 左右山形鍓寸法変化。

iii）防撓材の闭側に平板の存する模型の実験
AI 型, E 系統 5 種 10 ケ
幅，厚，型鋼一定，長さ変化。
F, H, I 系統 7 種 14 ケ
板の片面に防撓材を附す。
$\mathrm{G}$ 系統 3 種 6 ケ
中央防撓材の寸法変化す。
A 型 2 種 4 ケ
左右辺を枠で支持す。

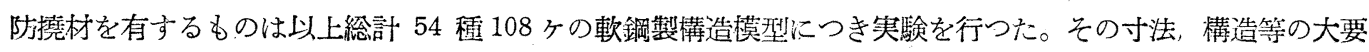
を表 2 亿示す。

\section{$\S 2 \cdot 2$ 模型寸法, 元答曲等の実測}

模型の計画寸法は表 1 ，表 2 亿示す通りであるが，実際に出来上つたものにつきその寸法を実戝した所，長さ 幅等の寸法は計画寸法に比し誤差は概秝 $0.5 \mathrm{~mm}$ 程度以下であつた。

板厚は一定間隔に羁書いた縱聩線の交点でギャップゲージマイクロメーターで測定した所，平均值に対する偏 差は数\%程度の値を示した。

又前記緃横線上で鋼板面の凹凸を測つたところ，極く少数の模型を除き元彎曲 $0.5 \mathrm{~mm} 22 \mathrm{~mm}$ 程度以下であ つた。

以上模型の寸法，元彎曲等を実測した結果を綜合すれば，その製作は良好なるるのであることが判る。

\section{$\S 2 \cdot 3$ 使用材料の材料試験成䋖}

模型に使用した鋼板並びに型鋼から引張試駼片を採取し試䀫したとこう，引張強さ概权 $40 \sim 48 \mathrm{~kg} / \mathrm{mm}^{2}$ ，伸 率 $20 \sim 28 \%$ ，ヤング倸数 $2.0 \sim 2.1 \times 10^{4} \mathrm{~kg} / \mathrm{mm}^{2}$ 程度て船体朋任延鋼材として普通の材質であることを示した。

\section{$\S 2.4$ 実験装置並に実験方法}

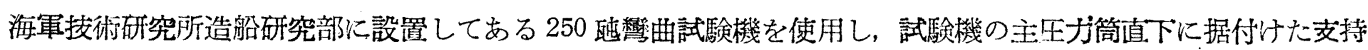
台上に模型を鉛值に立て，主王力筒下部に取付计た荷重用梁を模型上面に滵着する栐調整して荷重を加える。

（図 1 参照）但し周辺支持の矩型平板の実験に於ては模型は支持枠で支えて実験を行う。(図 2)

荷重は階段的に増加し，途中で扂すことなく模型の圧壊する汽加圧す。荷重は主圧才筒内の油圧により作動す る振子型動す計で読んだ。

\section{$\S 2 \cdot 5$ 測 定 装 置}

模型に荷重を加えた埸合 荷重に対し次の諸量を計浿した。即ち正縮による全長の縮み量を上下の山形鋼の間 に取付けられたダイヤル・ダーデで測り，板面に直角方向の変位即ち横撓み量をがイヤル・ゲーヂ並びに型取り 装置で測定した。（図 3 参照）横撓み量は板の中心線上及び防接材位置で測つた。向一部の模型では防撓材の据 


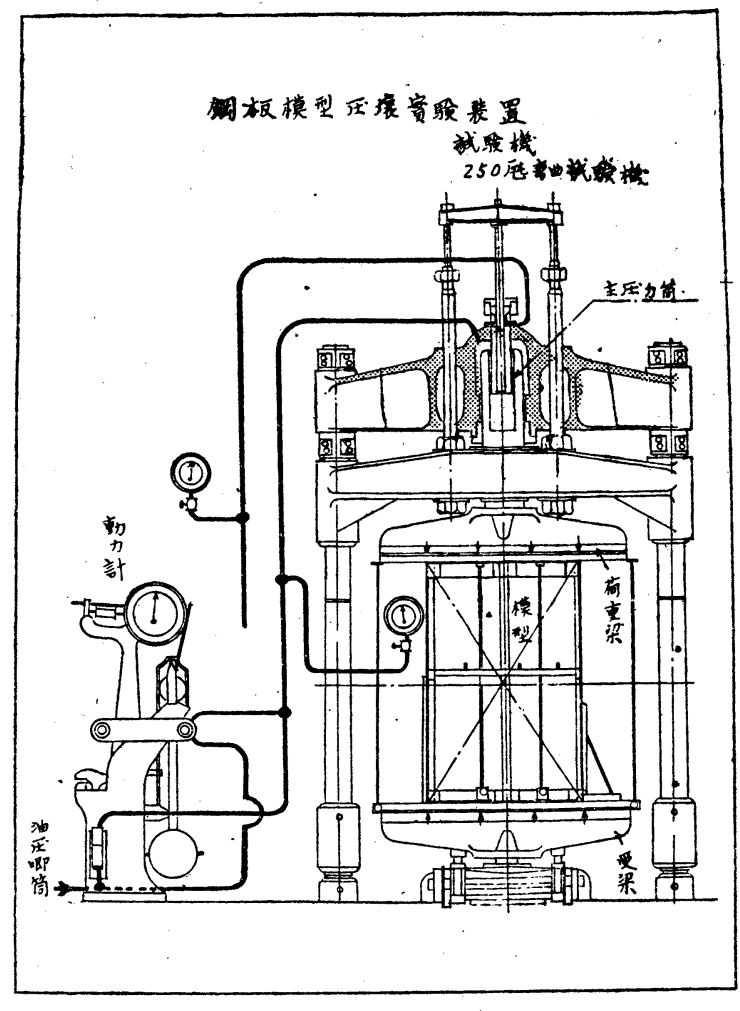

第 1 図

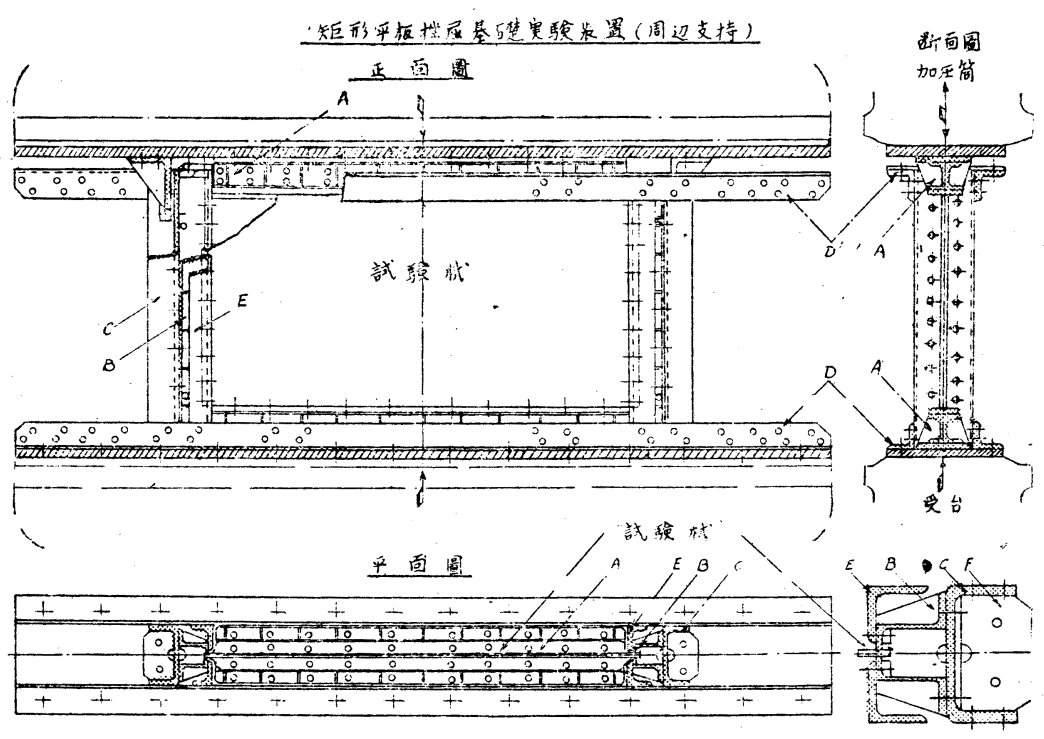



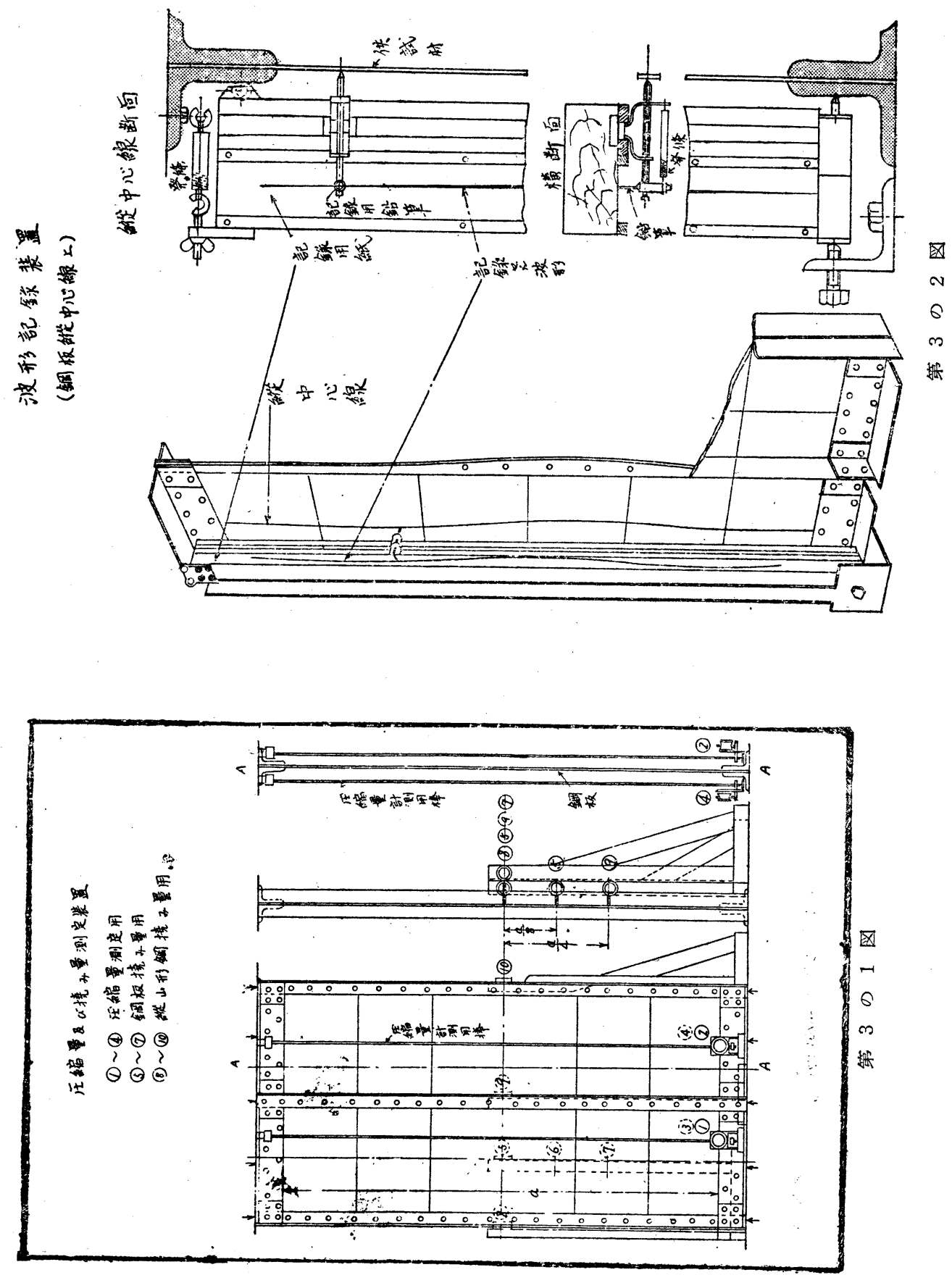
れを求める為气のフランヂ位置にダイヤル・ゲーヂを設置したものもある。歪の分布を測る為にオクイゼン式 の歪計を取付计歪を測定したものもある。

\section{第3章＼cjkstart鋼板の挫届並に压壊強度}

\section{$\S 3 \cdot 1$ 圧䑿を受ける周辺支持の矩形平板の挫屈限界}

圧縮荷重を受ける周辺支持の矩形平板の挫屈限界応力に就いては計算值と既往の実験值が良く一致せぬことは 既に記述した通りである。挫屈に関する実験を行つた場合, 試験材の有する元彎曲, 偏心荷重の存在等実験の不 備により，荷重に対する縮み量乙攵び横撓及量は共に挫屈限界点附近で徐々に変化し，理論の示す様な急激な変化 をしない。それで限界点の決定に困難を感ずるのが普通である。(困 4 ，図 10 参照) 従つて何等かの機械的決定
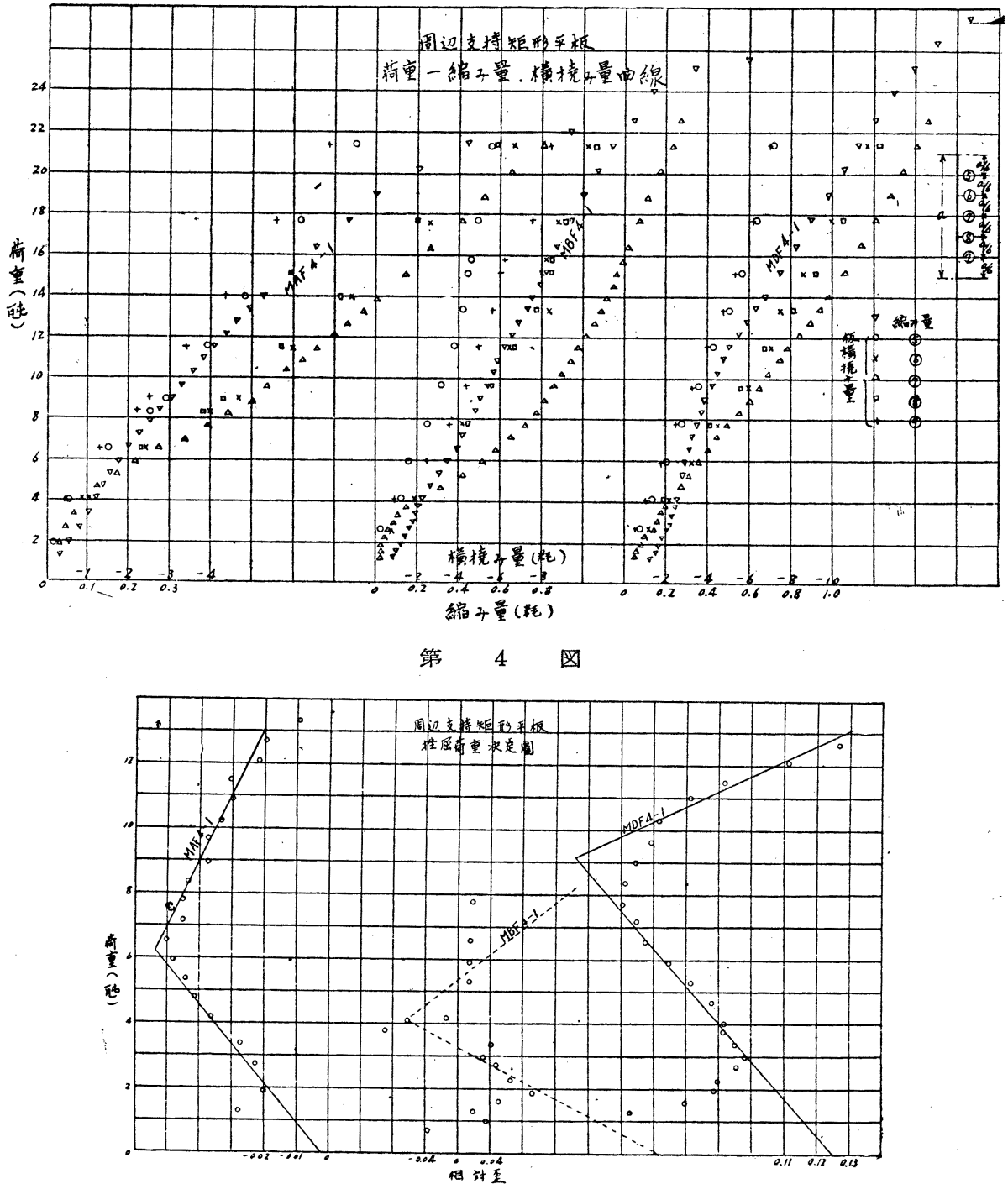

第 5 园

法によつて一定の標準で定めないこと，限界値は相当の範囲に任意に決められることになり，それを理論值と比 べても無意味となる。此の様な欠陥を除く為に考案せられたるのに, R. V.Southwell(41) の方法, Southwell の 方法を改良した L.H. Donnell(42) の方法, 並に H. L. Cox(13) の方法等があるが, 本研究では主として Cox の方法によつて挫屈限界点を決定することとし，(図 5 参照) Cox 法で決定し得奴場合は Donnell 法による值を 


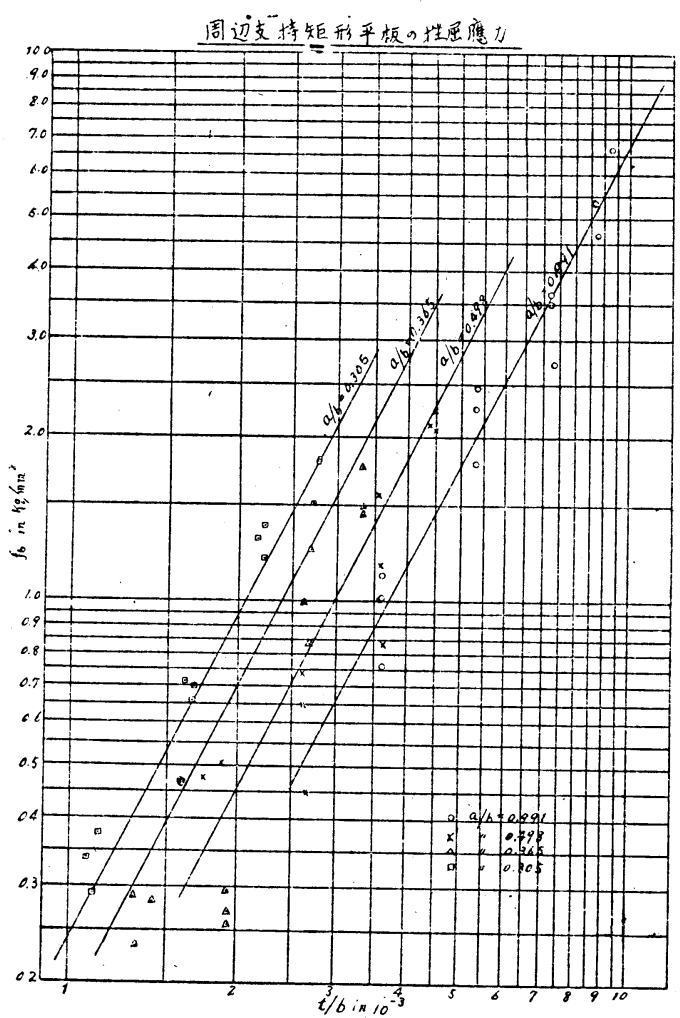

第 6 図

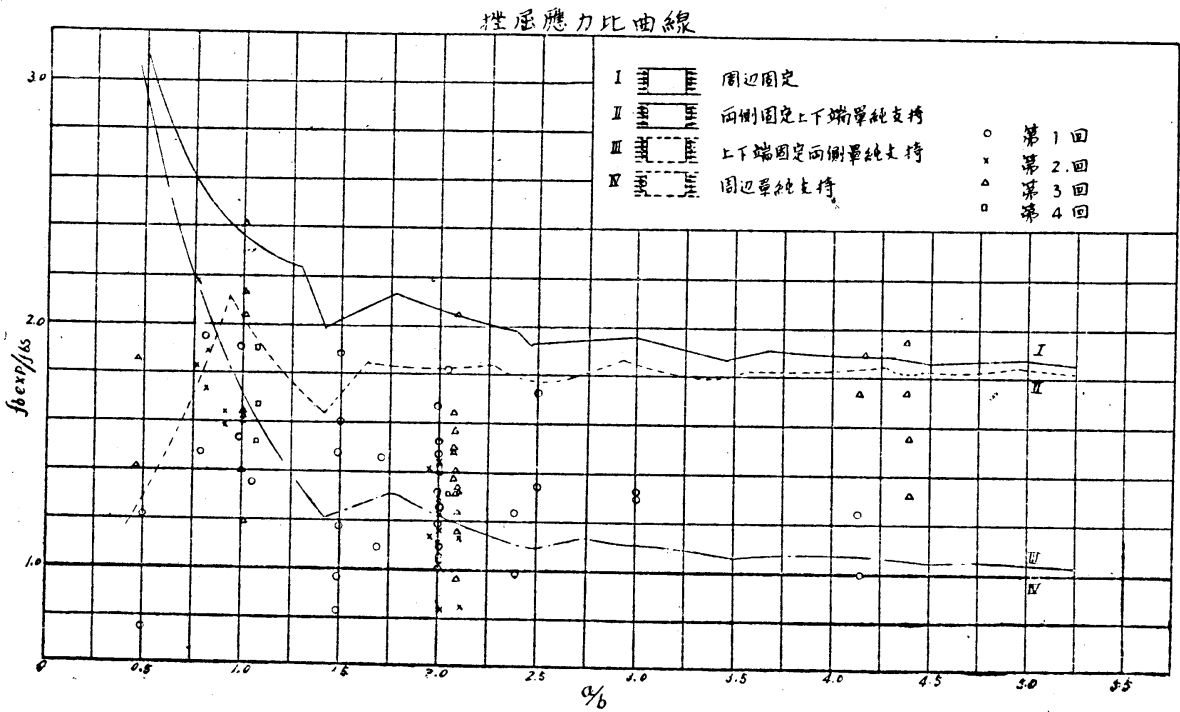

採用した。

第 7 図

その結果は表 3 文び図 6 に示す如く概ね周辺支持の計算值に等しい結果を得，本実験の如き支持方法に対して は Bryan の計算值を用いて挫屈限界值を算定して大差なきことを示している。

\section{$\S 3 \cdot 2$ 周辺に防撓材を有する矩形平板の挫屈限界}

周辺を防撓材で支えられた釟合，板の挫屈限界点は前項同椂荷重縮み量曲線の折れ角を Cox 法で決定し，夫 を挫屈限界点として採つた。その結果は表 4 に示す。図 7 は挫屈限界点の垁験值と, 周辺支持の場合の計算值と 


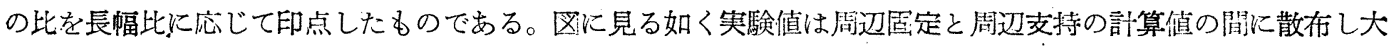

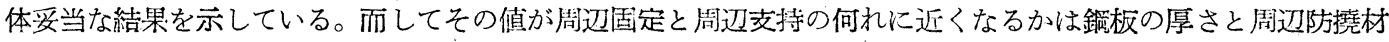
の曲げ剛性及び㨝り剛性との相対関係に支配されるべきであるので，図 8 の如く印点した所，大体に於て防撓材 の剛性が大になるに従つて夙辺固定に近くなることを示しているが，佮相当の偏差を示するのあり，数量的の決 論を得るには至らなかつた。此の様に偏差の現れる主な原因としては模型の有する元彎曲の大小が考えられるが 末だ数量的に決め得るには至つていない。

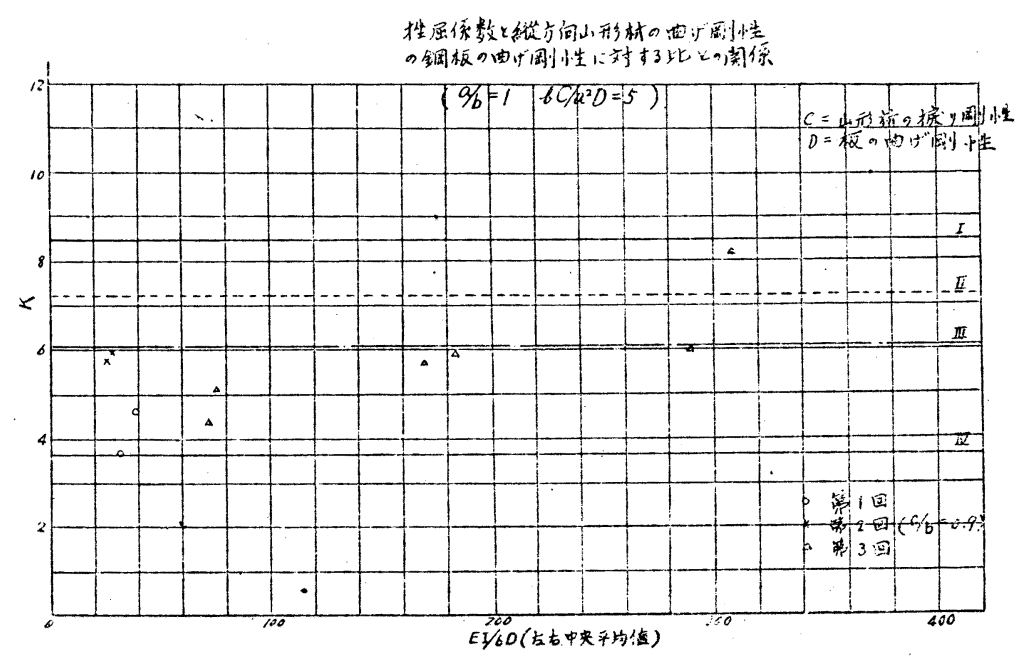

第 8 四

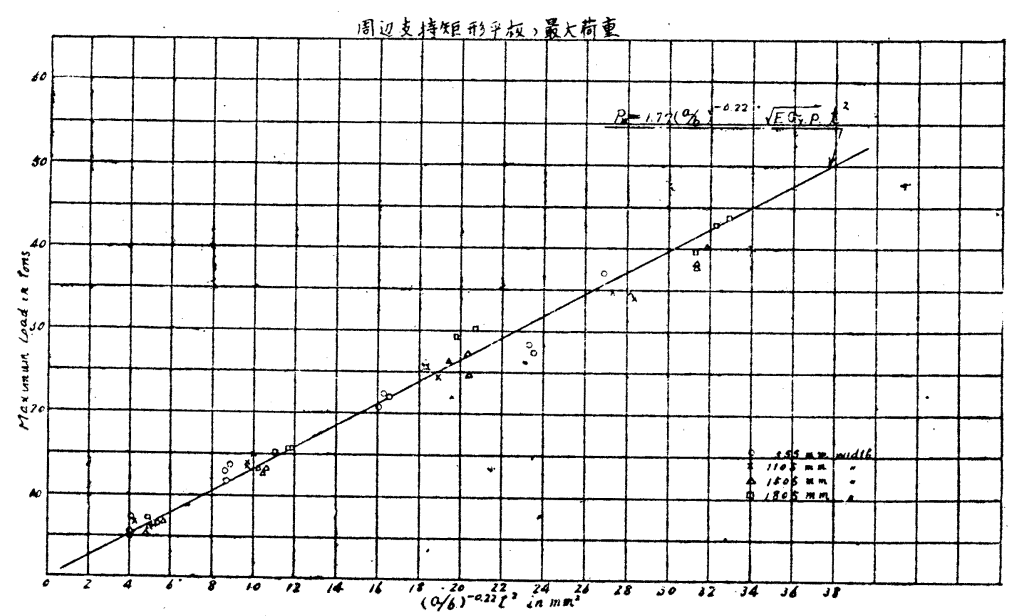

第 9 因

\section{$\S 3 \cdot 3$ 圧縮を受ける矩形平板の最大荷重}

周辺支持の場合に於て挫屈限界点以上の荷重に耐兄得ることは図 4 に明かな所である。限界点以上に荷重を加 えて板が遂に夫以上荷重を支え得なくなり，区壊する際の最大荷重の值は表 3 亿示す通らである。此の最大荷重 は von Kármán(17)によれば幅の大小に関係しないのであるが，実駼結果は幅の影響が現れている。一方 $\operatorname{Cox}^{(6)}$ はその解析で幅の影響を入れている。そこで幅の影響をる考慮して von Kármán の式に補正を行うこととして 次の様に実験式を定めた。

但乙

$$
P_{m}=1.77(a / b)-0.22 \sqrt{E \cdot \sigma_{X \cdot P}} \cdot t^{2}
$$

$$
P_{m}=\text { 最大荷重 }
$$




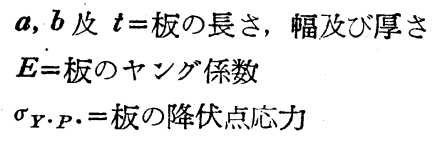

此の実験式による計算值と実測值の関係を見ると，全試験片 47 ケ中，䛊差 $33 \%$ を示した 1 ケを除き，誤差 10〜20\%のもの 7 ケ, 残りの 39 ケは 10\% 以内の誤差である。故に圧壊の際に於ける最大荷重は本式を用いて 充分実用に供し得る結果の得られることを示している。(四 9 参照)

佮本実験の範囲に於ては, 最大荷重は挫屈限界荷重の約 2 7 倍の範囲にあり, 大体板厚薄きもの程最大荷重 の割合大で，又幅の広いもの程最大荷重の割合大なる傾向を示していることは注意を要する。

\section{第 4 章 防 撓材部の挫 屈}

\section{$\S 4 \cdot 1$ 有効防撓材の設定}

鋼板はその挫屈後は有効剛性を減ずるが更に挫屈荷重以上の荷重に耐えることは前章に記述した通りである。 又その有効剛性は板の周縁固定状態，周縁圧縮忘力の大いさ及び板の長幅比等によつて変化することも既汇知ら れている通りである。

鋼板挫屈後に生起する防撓材の挫屈を論ずる為には此の板の挫屈後の有效岡性を明かにせねばならぬことは論 を俟たない所である。併し夫には理論的にも相当の煩雑さを伴い, 文実験的に決定するにも困難がある。註)

夫で普通には逐次近似法を採用しているが，本研究に於てはその煩雑さを除く為，簡単な仮定によつて解析を 試みた。即ち板の挫屈限度を超えた直後は，その有效剛性は $1 / 2$ に減少し，その後徐々に有效剛性が減じて行く が，1/2 よりの減少は周縁応力の相当の範囲ではあまり大きくはないので，その間の有效剛性は $1 / 2$ で一定と仮 定して板の挫屈後の解析を行うこととした。勿論此の樣な仮定は正しくない。特に限界応力を離れる程その差は 大きくなる。併し図 10 に示寸如く，此の仮定によつて描かれた荷重一縮及量の関係を示寸直線は相当良く実験

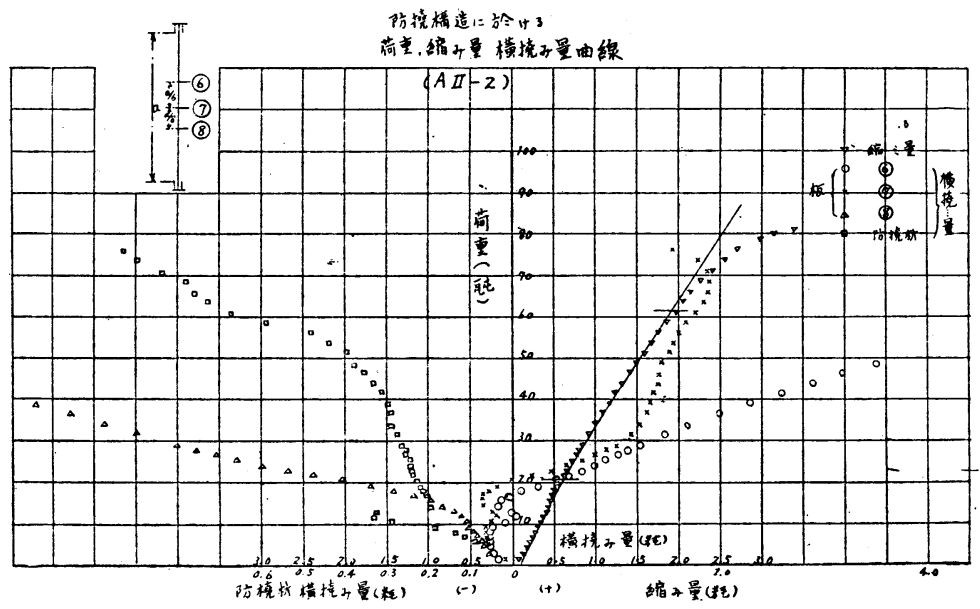

第 10 の 1 図

と一致して居り，此の仮定の実用性のあることを示している。

此の様に有効岡性を $1 / 2$ とすることは板幅の $1 / 2$ が有效に働くものとすることになる。此の有効部分が防㩭材 と共に働き，板幅の $1 / 4$ 宛が両側の防撓材と一体となつていると考えることが出来る。斯様に防撓材と板幅の $1 / 4$ の板（防撓材の両側に板がある時は両側に各幅の $1 / 4$ 宛を附し，片側のみに板がある時は，その幅の $1 / 4$ を 附す）とで一体になつた柱状体を考兄，之を有效防撓材と唱兄，此の有効防撓材について細長比を求めて解析を 行つた。板の残りの部分は大体挫屈応力程度の応力を負担することが明かにされて居り（例えば E.E. Sechler

(註) $\operatorname{Cox}(6)$, Marguerre ${ }^{(20 j}$ 等の結果を比較すると，板の周辺に於ける条件の仮定によつて結果に相当の差 異を生ずることが判る。又解の近似度によつても異るが，夫を正磪な条件の基に解くことは不可能に近 い。実験的にも, 試験片の仕上りの精度, 䛠差等の為に決定は難しい。 


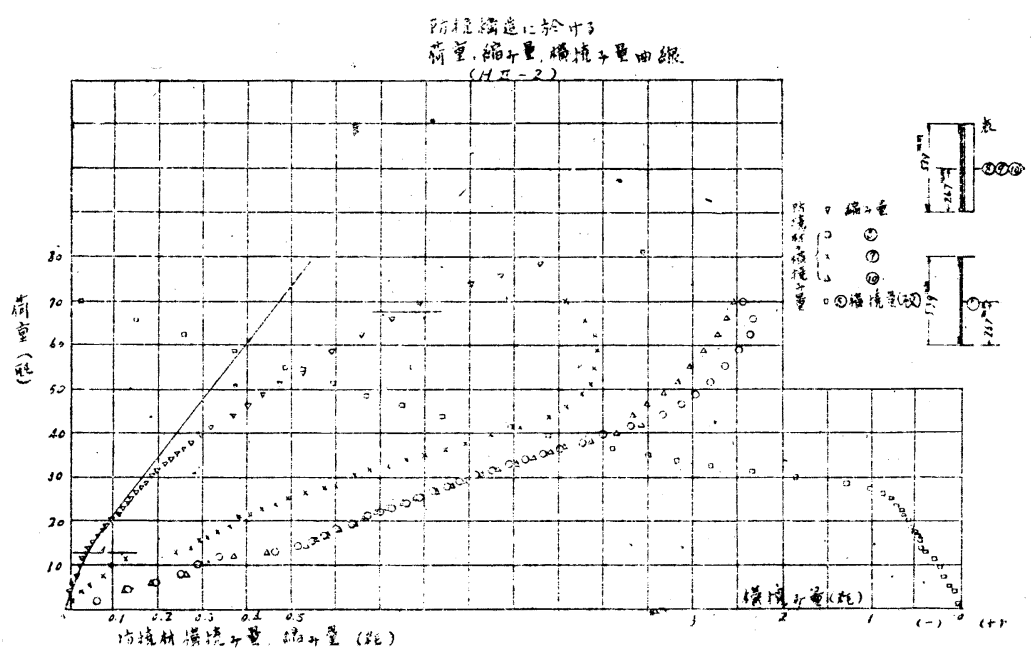

第 10 の 2 図

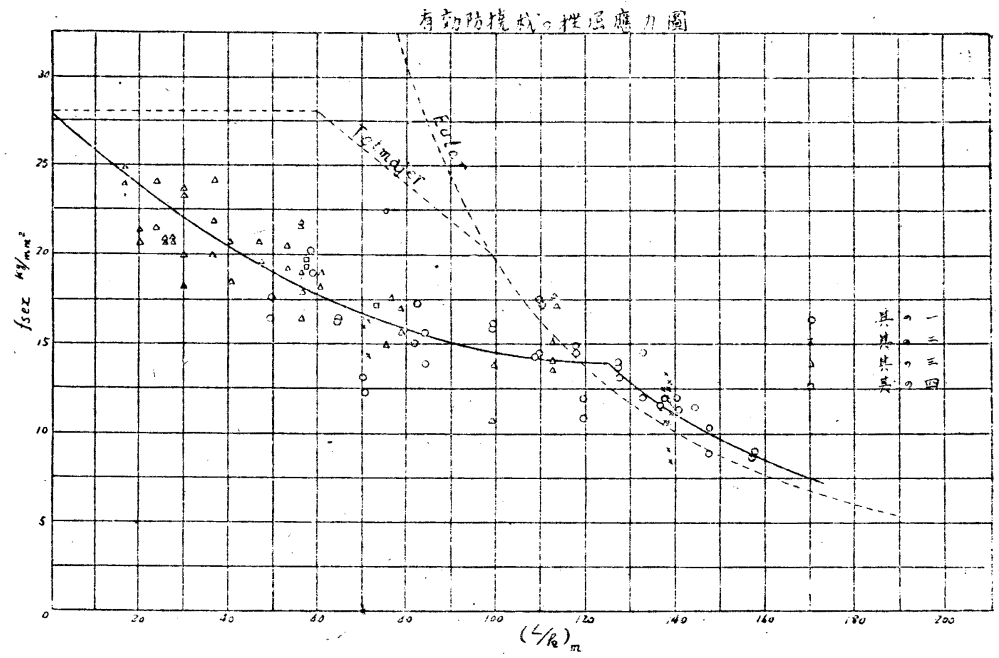

第 11 図

(31)), 又本実験に於ても,オクイゼン式歪訫により大体その正しいことが確められたので，板の挫屈後は此の部分 は常に挫屈応力に等しい応力を受持つものとした。即ち挫屈応力に板厚と板幅の $1 / 2$ (非有效部分の板の断面積) を乗じたものを全荷重より差引き，残りの荷重が有效防撓材によつて負担されるものとして解析を行つた。

\section{$\S 4 \cdot 2$ 有效防撓材の挫屈荷重}

前項汇記述した通り板の挫崫後荷重一縮及量実測值は有效防撓材の計算直線と略々一致しているが，荷重の増 加と共に実測値は㳥次此の直線より離れて縮み量の増加が大となる。(図 10 参照) 此の直線より離れ縮文量の急 增する附近をCox 法で执大して曲線の折れ角を求め，その点を有效防撓材の挫屈荷重として採つた。斯く決め られた挫屈荷重より，板の非有效部分の負担する荷重を差引き，有效防撓材の断面積で割つて有效防撓材の挫屈 応力を求める。即ち，

$$
f_{s}=\left\{P_{\mathrm{II}}-f_{b} \sum_{p}\left(1-\frac{1}{n}\right) b t\right\} / \sum_{s}\left(A_{s}+\frac{1}{n} b t\right)
$$

此処飞 $\quad f_{s}=$ 有效防撓材の挫屈応力

$P_{\mathrm{II}}=$ 有效防撓材の挫屈時汇於汁る荷重 


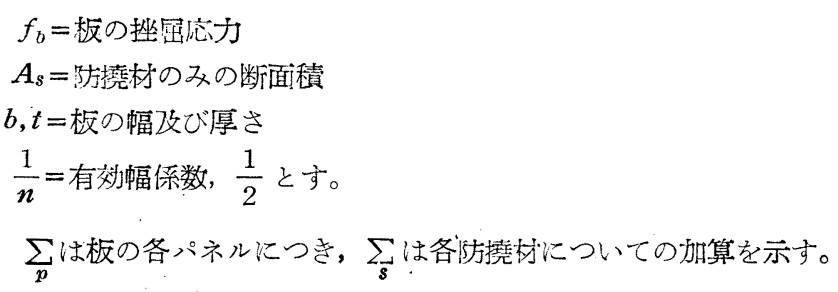

此の挫屈泣力を有効防撓材の細長比に対して印点した所, 因 11 に示す様になつた。防撓材寸法の異るものを 組合した構造では細長比の平均值を採つて印点した。大体細長比 120 以上では両端回転端つ Euler 值に近く, 夫以下では Euler 曲線より低く，細長比が零に近ずくと共に材料の降伏点 $28 \mathrm{~kg} / \mathrm{mm}^{2}$ に近ずく傾向を示す。 実験值の平均值は大略次の式で示すことが出来る。

$$
\begin{aligned}
& f_{s}=1.1 \frac{\pi^{2} E}{(L / k)_{m}^{2}} \\
&= 28\left\{1-0.00803\left(\frac{L}{k}\right)_{m}+0.0000323\left(\frac{L}{k}\right)_{m}^{2}\right\} \\
&(L / k)_{m}<125 \text { に対し }
\end{aligned}
$$

但し $(L / k)_{m}=$ 有效防撓材の細長比の平均值

此の実験式の值と実験值との偏差は十数箇のものを除き大約 $10 \%$ 内外となり先ず実用上伎用可能と思われる。 份以上の結果に於て $L_{i}^{\prime} k$ の小なる部分では挫屈は Euler 挫屈とは異り局部的の㱀波の発生又は捩机に上る挫 屈であるので，細長比に対して印点することは不適当と思われるが普通に行われているのに彷つたものである。 又細長比の小なる部分では他の著者の值に比し低い值を示している。従つて上記の様な挫屈限典点を採らず, 最 大淔を挫屈荷重として採るべきではないかとも考兄られるが，その様にすると結果の偏差は大となり緾りが悪 い。夫で上記の㥞は限界点を定め, 総て $L / k$ を基汅して解析することにした。

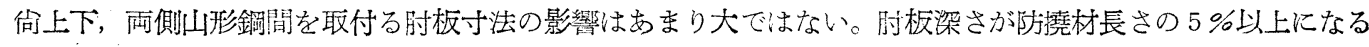
と挫屈荷重は稍々大になる様であるが，その程度は肘板ない場合の $10 \%$ 増以下である。

\section{第 5 章 防撓薄板構造の压壊強度}

\section{$\S 5 \cdot 1$ 防撓薄板構造の圧壊}

第 1 章に於て記述した如く防撓薄板構造物が全体として Euler 挫屈を生ずる埸合には挫屈限界荷重が構造物 の耐光得る最大荷重であると考兄られている。然るに細長比が大で Euler 挫屈を生じた模型に於て, 前章に記 述した方法により定められた挫屈荷重は既に Euler の計算值より高い值を示し, 従つて最大値は更に高いこと になる。然し有效防撓材として加算した板幅の $1 / 2$ は大に過ぎることは明かである。即ち有効防撓材としては過 大に見積つて計算を行つても訫算值よりも実測值の方が大になるのである。故に挫屈を生じた場合に酎兄得る最 大荷重を挫屈限度によつて決定することは更に考慮を要するものと考兄られる。佮念の為最大荷重を細長比に対 し印点すれば，可成りの散布を示し，最大荷重を挫屈限として採ることの不可なることを示している。

\section{$\S 5 \cdot 2$ 最大荷重を与える条件に対する理論的考察}

Euler 挫屈の際の挫屈荷重が王壊の最大荷重でないとすると, 最大荷重となる条件を考える必要がある。

真直な細長い弹性棒に軸玨力を加えた場合に棒の長さ軸匠力の大きさに忘じて棒は屈曲した形で平衡状態を保 つことはエラスティカの開題として知られている通りである。薄板防撓構造に於ても挫屈後は此のエラスティカ の状態となり，軸庄正に応じ定まつた曲りを生ずるものとする。斯くすれば防撓材は曲价と圧縮を同時に受ける ことになり，その為に防撓材に生ずる最大の压縮芯力が材料により定まつた一定の応力例えば降伏点に達すると 防撓構造の最大荷重に達するものとする。斯様に考えてその条件を求めると次の様になる。

軸王力 $P$ を受ける反曲点を有するエラスティカに於て棒の曲け剛性を $B$ ，棒の曲線長さを $S$ ，その点の傾角 を日とすると平衡の方程式の第 1 積分は

$$
\frac{1}{2} B\left(\frac{d \theta}{d s}\right)^{2}+P(\cos \alpha-\cos \theta)=0 *
$$

* 例光ば A.E.H. Love : A Treatise on the Mathematical Theory of Elasticity 4 th ed. p. 402 
但し $\alpha$ は反曲点 $A$ に於ける傾角で， $s$ は反曲点より测るものとす。

$$
u=s \downarrow \overline{F / B}
$$

改び $\sin \frac{1}{2} \theta=\sin \frac{1}{2} \alpha \cdot \sin \varphi$.

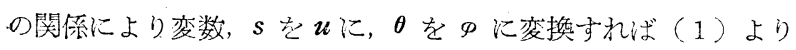

$$
\begin{aligned}
& \frac{d \Phi}{d u}=\sqrt{1-k^{2} \sin ^{2} \Phi} \\
& \text { 但し } k=\sin \frac{1}{2} \cdot \alpha
\end{aligned}
$$

上式を積分ずれば

$$
u=\int_{\frac{\pi}{3}}^{\varphi} \frac{d \phi}{1-k^{2} \sin ^{2} \varphi}=\int_{0}^{\varphi} \frac{d \rho}{1-k^{2} \sin ^{2} \phi}-\int_{0}^{\frac{\pi}{1}} \frac{d \phi}{1-k^{2} \sin ^{2} \varphi}
$$

或は

$$
u+K=\int_{0}^{\varphi} \frac{d \phi}{\sqrt{1-k^{2} \sin ^{2} \varphi}}
$$

(2a) の右辺は第 1 種楕队積分で Legendre-Jacobi の標準形であり，Kは母数 $\boldsymbol{k}$ の第一種完全棈円積分である。 直角坐標を $x, y$ とすると

$$
\frac{d s i}{d s}=\cos \theta, \quad \frac{d y}{d s}=\sin \theta
$$

及 (2a) の逆函数ととれば Jacobi の梋凹函数となる。

$$
\begin{aligned}
& \operatorname{sn}(u+K)=\sin \varphi \\
& \therefore \quad \sin \frac{1}{2} \theta=k \sin \varphi=k \operatorname{sn}(\boldsymbol{u}+K) \\
& \therefore \quad \frac{d \theta}{d u}=2 k \operatorname{cn}(\boldsymbol{u}+K) \\
& \therefore \quad \frac{d \boldsymbol{x}}{d s}=\cos \theta=1-2 k^{2} \operatorname{sn}^{2}(u+K)=2 d n^{2}(u+K)-1 \\
& \therefore \quad x=\sqrt{\frac{B}{P}} \int_{0}^{u}\left\{2 d n^{2}(u+K)-1\right\} d u \\
& \quad=\sqrt{\frac{B}{P}}[-u+2\{\operatorname{Eam}(u+K)-\operatorname{Eam} K\}]
\end{aligned}
$$

㕛 $\frac{d y}{d s}=\sin \theta=2 k s n(\boldsymbol{u}+K), \overline{1-k^{2} s n^{2}(\boldsymbol{u}+K)}=2 k \operatorname{sn}(\boldsymbol{u}+\boldsymbol{K}) d \boldsymbol{n}(\boldsymbol{u}+\boldsymbol{K})$

$$
\therefore \quad y=2 k \sqrt{\frac{B}{P}} \int_{K}^{u+K} \operatorname{sn}(\boldsymbol{u}+K) d \boldsymbol{u}(\boldsymbol{u}+K) d(\boldsymbol{u}+K)=-2 k \sqrt{\frac{B}{P}} c u(u+K)
$$

$y$ の最大值となる $M$ 点では $\theta=0$, 故に（4）より $u=K$ でむることがわかる。隹つて $M$ 点の $y$ の值，即 ら最大值を齐とすると，

$$
\bar{y}=2 k \sqrt{\frac{B}{P}}
$$

$M$ 点の曲げセーメント $M_{m}$ は

$$
M_{m}=P \cdot \bar{y}=2 k_{V} \overline{B \cdot P}
$$

又は曲げモーメントを $M=B \cdot \frac{d \theta}{d s}$ より求めると，

$$
\left.M_{m}=B \cdot\left(\frac{d \theta}{d s}\right)_{m}=\sqrt{B \cdot P} \cdot 2 k c n(u+K)\right]_{n=K}=2 k_{\imath} / \overline{B \cdot P}
$$

となり（9）と一致することがわかる。 
従つて棒の受ける最大応力は $M$ 点で起り，その值は值接力によるものとの和として过の如く求められる。

$$
\sigma_{\max }=\frac{P}{A}+\frac{P^{-} \cdot y}{I} \cdot \eta
$$

但し $A$ は棒の断面積， $I$ は断面二次モーメント， $\eta$ は中立軸より周縁迄の距離の内大なるものである。

以上で一伈最大忘力が求められたが，母数 $k$ (徉つて $\boldsymbol{\alpha}$ ) を決めねば実際に計算は出来ない。 $k$ を決めるには 棒の長さの関倸を用いれば良い。

即ち棒の最初の長さを $l$ とすれば,

$$
l=2 \int_{0}^{l^{\prime} / 2}\left(1+\frac{P \cos \theta}{E A}\right) d s=2 \sqrt{\frac{B}{P}}\left[K+\frac{P}{E A}\{2 \operatorname{Eam} K-K\}\right]
$$

但し $l^{\prime}=\int_{0}^{l^{\prime}} d s=2 \sqrt{\frac{B}{P}} K$ (棒の変形後の長さ)

(11) の関係より荷重 $P$ に対し $K$ が沈まり，徉つて $k$ が定まり， $P$ が与えられたとき（10）より $\sigma_{\max }$ が求 められることになる。 $P$ の代りに $\lambda \stackrel{=}{=} / P_{E}$ とおいて (11) を書き直し， $\lambda$ に対し $k$ を定める関係式にすると，

$$
\sqrt{\lambda} \pi=2\left[K+\lambda \pi^{2} \cdot \frac{I}{A l^{2}}(2 \operatorname{Eam} K-K)\right]
$$

但し $P_{E}=\frac{\pi^{2} E I}{l^{2}}$ (棒の Euler 挫屈荷重)

丈 (10)より

$$
\frac{\sigma_{\max }}{E}=\lambda \pi^{2}\left(\frac{I}{A l^{2}}+\frac{2 \eta}{l} \cdot k \frac{1}{1 \lambda \pi}\right)
$$

$\lambda$ が決まると (12)，(13）の関係より $\sigma_{\max }$ が汱まる。

今 (13) の $\sigma_{\max }$ の值が或る一定值例えば降伏点になつた埸合に $P$ は最大值 $P_{0}$ に達するものとする。(12), (13) より $\sigma_{\max }$ の一定值に対する $\lambda_{0}\left(F_{0}\right.$ に対沁する值) を求めると， $\lambda_{0}$ の值は柱の $I / A l^{2}, 2 \eta / l$ の值に左右 せられる。

$$
\begin{aligned}
\text { 即ち } & \lambda_{0} \pi^{2}=f\left(\frac{I}{A l^{2}}, \frac{2 \eta}{l}\right) \\
\text { 或は } & \frac{P_{0}}{A E}=\frac{I}{A l^{2}} \cdot f\left(\frac{I}{A l_{2}}, \frac{2 \eta}{l}\right) \equiv \emptyset\left(\frac{I}{A l^{2}}, \frac{2 \eta}{l}\right)
\end{aligned}
$$

従つて最大荷重 $P_{0}$. は防撓材の $\frac{I}{A l^{2}}, 2 \frac{\eta}{l}$ の函数であるから夫に対して解析を行えば良いことになる。

\section{$\S 5 \cdot 3$ 防撓構造物の圧壊時に於ける最大荷重}

前項の理論的解析により最大荷重 $P_{0}$ が $\frac{I}{A l^{2}}, 2 \frac{\eta}{l}$ の函数であることが判つたので, 有效防撓材につき以上 の量を求め, 夫に従つて実験結果を䚙析した。即ち最大荷重の実測值から板の非有效部分の負担する荷重を美引 いて残りを有效防撓材の最大荷重として取揆い，図 12 に示す通り $\frac{I}{A_{0} l^{2}} \times\left(\frac{l}{2 \eta}\right)^{1.5}$ を穔軸に採つて実験檤を印 点した所，点は略々縓つた結果を示し，解析の基とした考方方の正しいことを示している。

此の結果から実験式として次の通りに定めた。即ち

$$
\begin{aligned}
& \frac{P_{0}}{E A_{0}}=0.167 \frac{I}{A_{0} l^{2}} \cdot\left(\frac{l}{2 \eta}\right)^{1.5} \\
& =9.70 \times 10^{-4}+0.020 \frac{I}{A_{0} l^{2}}\left(\frac{l}{2 \eta}\right)^{1.5} \\
& \frac{I}{A_{0} l^{2}}\left(\frac{l}{2 \eta}\right)^{1.5} \times 10^{3}<6.6 \\
& \text { " > }>6.6
\end{aligned}
$$

実験結果を此の様に折れ角を持つた 2 本の直線で大体表わすことが出来るが，折れ角より下の $\frac{I}{A l^{2}}\left(\frac{l}{2 \eta}\right)^{1 \cdot 5}$ の小なる部分では Euler 挫屈を示したものが含まれ, 夫以上の部分に入るものでは捩り又は局部的挫撓を示し たものが多い。

换り挫屈又は局部的挫屈を生じたものをも同じく $\frac{I}{A_{0} l^{2}}\left(\frac{l}{2 \eta}\right)^{1 \cdot 5}$ を基にして印点することは根扰にそしい訳で あるが，一応夫等も同じに扱つた。その結果此の部分では実験式に比し偏差は稍々大であるが，夫でも全体を通 


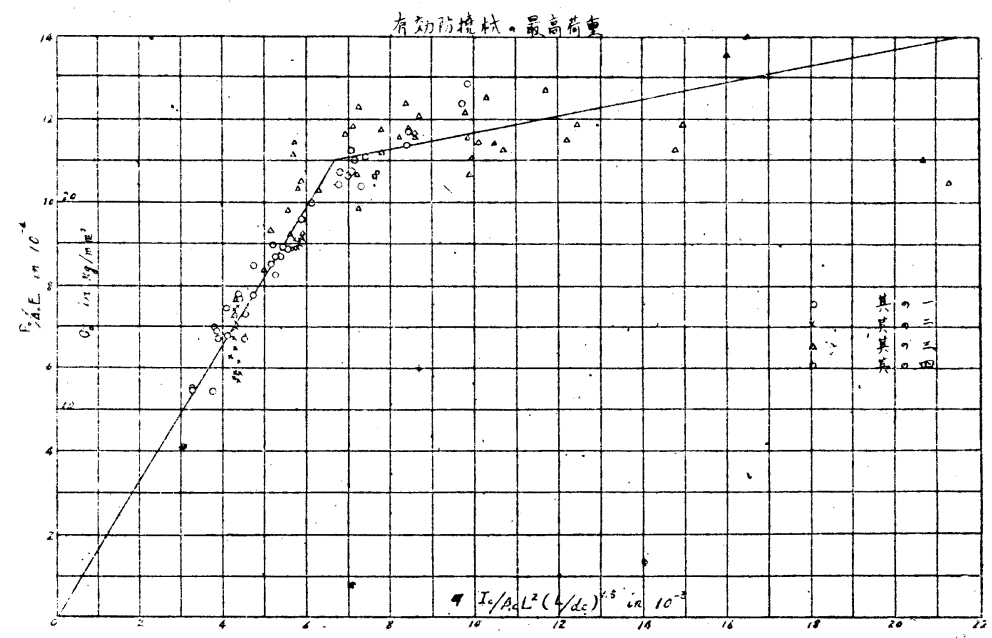

第 12 図

じ式による計算值と实験值との差は最大約 $20 \%$ で大多数は $10 \%$ 以下の差であつた。良つて上式は何れの破壤 の形式に対しても利用して实用上略々差支えないことが判る。

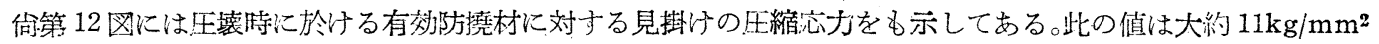
$\sim 28 \mathrm{~kg} / \mathrm{mm}^{2}$ の範囲にある。更に防撓薄板構造の全体についての平均王縮芯力を求めると最低 $8 \mathrm{~kg} / \mathrm{mm}^{2}$ 程度 迄下ることは注意を要する。

以上の取扱いに於て防撓材寸法の異るものが組合わされている塂合には，その内の弱い方の防撓材に対する $\frac{I}{A l^{2}}\left(\frac{l}{2 \eta}\right)^{1 \cdot 5}$ に対し印点した。その理由に最大荷重を超遌後は王縮歪の増加に対して急激に荷重負担力を失い，

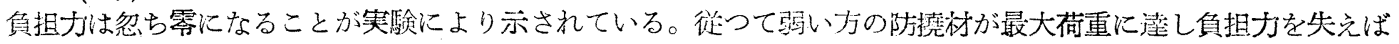

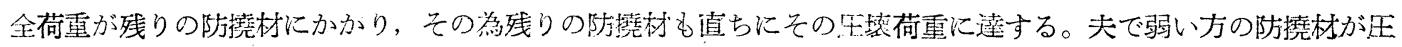
壊荷重に達した時が構造物全体の最大荷重になると若えられるからである。併し防撓材の強さに極端な差異があ

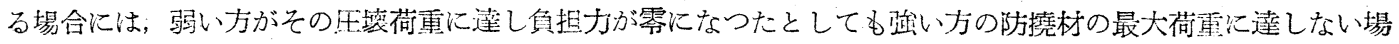

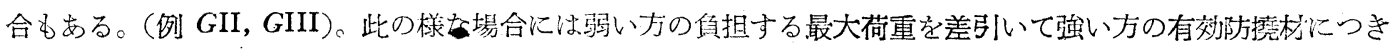

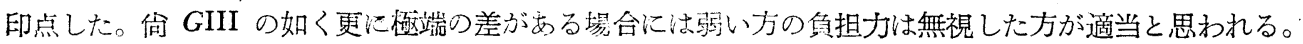

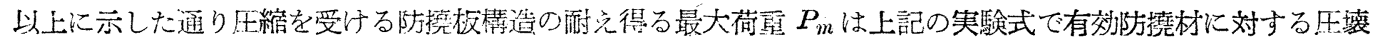
荷重 $P_{0}$ を求めれは次の式で定めることが出来る。即ち

$$
P_{m}=\frac{P_{0}}{E A_{0}} \cdot E \sum A_{0}+\frac{1}{2} \sum f_{b} \cdot b \cdot t
$$

但し $\sum A$ は有効防撓材の断面積の総和

$\frac{1}{2} \sum b \cdot t$ は板の非有效部分の断面積の和

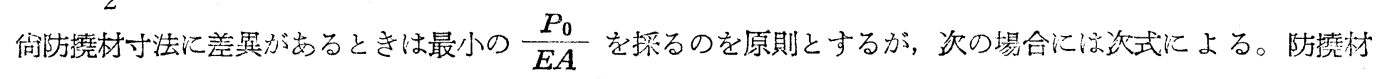
1 亿対し計算せられた犆を $\left(\frac{P_{0}}{E A}\right)_{1}$, 同 2 亿対し計算せられた值を $\left(\frac{P_{0}}{E A}\right)_{2}$, 䉼面積を夫心 $A_{1}, A_{2}$ とし, 且

$$
\begin{aligned}
& \left(\frac{P_{0}}{E A}\right)_{2}>\left(\frac{P_{0}}{E A}\right)_{1} \text { とす } \\
\text { 今 } & \left(\frac{P_{0}}{E A}\right)_{2} \cdot E A_{2}+\frac{1}{2} \sum f_{b} \cdot b \cdot t>\left(\frac{P_{0}}{E A}\right)_{1} E\left(A_{1}+A_{:}\right)+\frac{1}{2} \sum \cdot f_{b} \cdot \dot{b} \cdot t
\end{aligned}
$$

の場合には

$$
P_{m}=\left(\frac{P_{0}}{E A}\right)_{1} E A_{1}+\left(-\frac{P_{0}}{E A}\right)_{2} E A_{2}+\frac{1}{2} \sum f_{b} \cdot b \cdot i
$$




$$
\text { 或は } \quad P_{m}=\left(\begin{array}{c}
P_{0} \\
E A
\end{array}\right)_{2} E A_{2}+\frac{1}{2} \sum f_{b} \cdot b \cdot t \quad\left(\left(\frac{P_{0}}{E A}\right)_{1} \text { の特に小なる時 }\right)
$$

文有效防撓材の寸法の関係により $\frac{P_{0}}{E A_{0}}$ の実験式による值が挫屈荷重より低くなることがあるが，此の椂な際 には挫屈荷重を最大荷重として採るべきである。（図 13 参照）限界線より下方の部分では挫屈荷重となる。

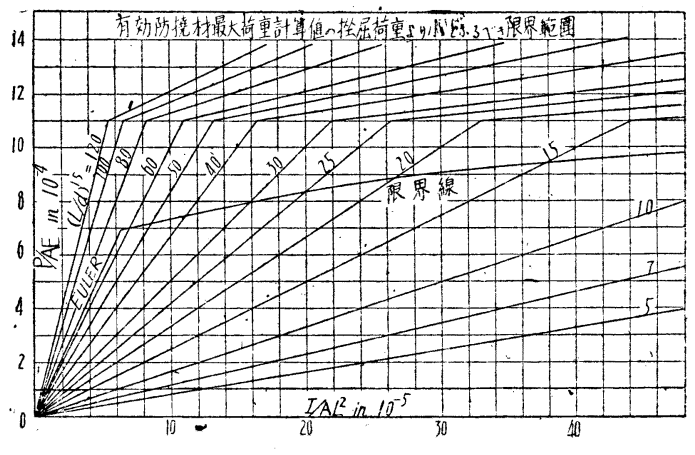

第 17 図

第 6 章，結

以上王縮を受ける薄板防暁構造の挫屈並に圧壊強度について実施した笑踰結果並にその解析に就いて記述した 所であるが，その結果明かにせられた諸点を列記すれば次の通りである。

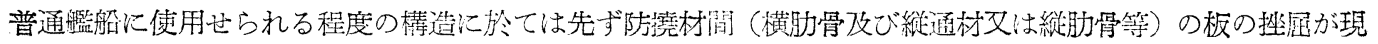
れ，防撓材が板と同時江挫屈することはない。

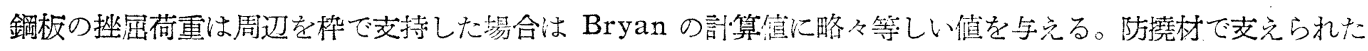

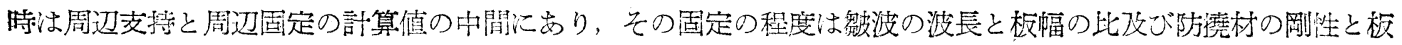
の岡性の比により左右せられる。

鋼板はその挫屈後王縮に対する岡性を減ずるが，挫屈荷重上上の荷重に耐える。問辺支持で鋼板のみで荷重を 支えている場合に於て鋼板の耐え得る最大荷重は本実駼の範囲で挫屈荷重の 2 7 倍の值を示した。（挫屈荷重 が特に低い結果を得たものでは此の比は 10 倍を超えたものもある。）俻此の比は板厚，長幅比によつて異る。

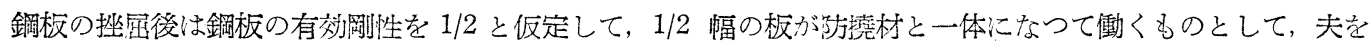
有效游岦材として解析を行つて実用上差支えない結果が得られる。

此の有效防墝材に就いてい解析すると，有效防撓材の Euler 挫屈荷重は薄板汸撓構造の耐え得る最大荷重て はない。

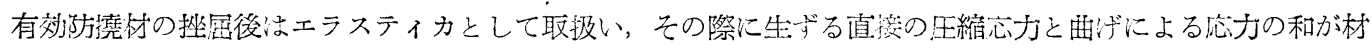
紏による一定值になつた場合に最大藏重こ達するものとして解析を行い, その結果最大荷重は有效防撓材の

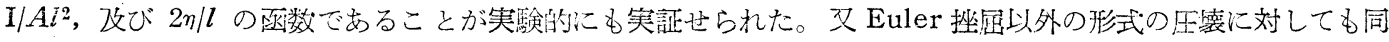

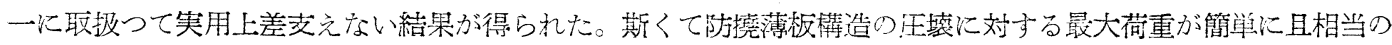
信頼度を以つて計算出来る。

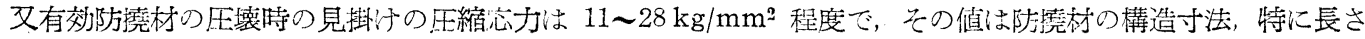
によつて変化する。佮鋼板の非有效部分をも含めた全構造物に対する見脚けの平均圧縮芯少は本実験範囲に於て 最低 $8 \mathrm{~kg} / \mathrm{mm}^{2}$ に迄下つたことは計画上特に注意を要する点である。

本研究の結果として得られた主な事項は以上の邀りであり，之によつて压縮才を受ける部分の最高荷重を求め る計算方式が明かにせられた。

又本研究結果により船体縌迹度計算に於て，压縮部分に刘し板の挫屈後は縱の連続部材の全断面積を算入する ことの不適当なことが明かにされた。即り全断面を有效とし計算した応力が，板の挫屈限界応力を超える場合に は，その超えた部分つパネルに対しては，幅つ $1 / 2$ を有效とし計算をやり直す必要がある。挫屈限界忍力を超え 
るパネルの断面積つ $1 / 2$ に挫屈限界応力及゙で中立軸からの距離を乗じた值を外力モーメントから差引いた值に対 して挫䜿したパネルの $1 / 2$ 面積を算入して求めた断面二次モーメントを用い忘力を計算し直す。斯して求めた応 力が此の計算の初めに挫屈を生ずると仮定したパネル以外のパネルの挫屈応力を超えないことが確められる汽繰 返す。斯様に縱通材部分に加わる応力は普通の計算による值より大となり船体構造の压壊強度の算定, 又は使用 状態に対する安全率決定济し重大な変更を招来するものである。

侗艦船計画上最大の問題の一である船体縦強度の極限強さ特に圧縮側に於忛る極限強さの算定の問題を解決す る為には更に次の諸点, 即ち曲げによる横断面の形状の崩れによる挫屈の問題, 横肋骨と縦通材の関聯の問題,

更に䑨側等の直角に結合せられた隅部の強度の問題等詳かにする必要のあることは論を㑨たない。併し横断面形 状の崩れによる挫屈の発生は現在程度の横肋骨に於てはその例を聞かず, 又円筒実験の結果に徵してもその発生 は殆んどないことより考光れば, 船体重量軽減上最も有利と考兄られている縦胁骨式構造に対しては本研究によ り得られた力式で最大荷重を求めれば夫は圧縮代対する極限強さを与兄るものと考兄る事が出来る。その際生縮 部が負担力を失えば隅部も先ず支え得ないと考兄られるからである。斯く観じ来ると本研究の成果は縦肋骨式構 造に対して綐强度の極限強さの算定に一つの指針を与えるものということが出来る。

終りに本研究に対し, 井口常雄, 徳川武定两先生より屡々有益なる御討論を頂いた事に対し深く感謝の意を表, する次第である。

又本実験の施行, 資料の整理等飞就いては，西谷海軍技師，立花游軍技手等の労に俟つ所多大である。併せて 謝意を表するものである。

\section{交献}

（1）加藤恭亮： 給油艦の縱強力に就て, 造船協会会報 44 号（昭和 4 年） 79 ～126. 玉井喬介： 油槽船さんぢ吕ご丸の上甲板の損傷に就て，造船協会々報 47 号（昭和 6 年）147 169. C.O.Kell : The Investigation of Structural Characteristics of Destroyers "Preston" and "Bruce". Trans. Soc. N. A. \& M. E. Vol. 39 (1931) 35 57.

(2) G. H. Bryan : On the Stability of Plane Plate under Thrust. Proc. London Math. Soc. Vol. 22 (1891) 54 67.

（3）妹沢克雄：薄板の安定, 造船協会会報 38 号（大正 15 年） 79 １06. On the Buckling of a Long Elastic Plate Under Edge Thrust. (西村源六郎々共著), 造船協 会会報 47 号（昭和 6 年) $129 \sim 142$.

On the Buckling under Edge Thrusts of a Rectangular Plate Clamped at Four Edges. 航研報告 No. 69 (1931).

四辺を固定し周圧を受ける矩形板の振動及其安定造船協会会報 49 号（昭和 7 年）87 93.

Buckling of a Rectangular Plate with Four Clamped Edges. Re-examined with an Improved Theory. 航研報告 No. 143 (1936).

(4) 山名正夫 : On the Elastic Stability of Aeroplane Structures. 東大, 工, 紀要 20 巻 (1933).

(5) G. I. Taylor : The Buckling Load of Rectangular Plate with Four Clamped Edges. Z. A. M. M. Bd. 13 (1933) 147 152.

(6) H. L. Cox : The Buckling of Thin Plates in Compression. A. R. C., R \& M. No. 1554 (1933).

(7) O. H. Faxen : Die Knickungsfestigkeit rechteckiger Platten. Z. A. M. M. Bd. 15(1935). 268 277.

(8) 井口鹿象：Allgemeine Lösung der Knickungsaufgabe für rechteckige Platten. Ing. Arch. Bd. 7 (1936) 207 215.

(9) J. L. Maulbetch : Buckling of Compressed Rectangular Plate with Built-in Edges. J. Appl. Mech. Vol. 4 (1937).

(10) S. Timoshenko : Einige Stabilitätsprobleme der Elastizitäts Theorie. Z. f. math. u. Physik Bd. 58 (1910) 347

(11) L. Schumann, G. Back : Strength of Rectangular Flat Plates under Edge Compression. N. A. C. A. No. 356 .

（12）横尾孝義：平面板及び曲面板の有效幅について, 航空学会誌 8 巻（昭和 16 年）200〜203.

(13) H. L. Cox, W. J. Clenshaw : The Strength of Ships' Platings. Inst. Engrs. \& Shipb. Scotland, Vol. $81(1937 \sim 8) 19 \sim 31$.

(14) R. Lahde, H. Wagner : Versuche zur Ermittlung der mittragende Breite von verbeulten Blechen. Luftfahrtforschung Bd. 13 (1936) 214 224. 
(15) J. Montgomerie : Experiments on the Compression of Samples of Deck Plating and the Application of Results to determine a Safe Limiting Thickness for Weather Decks in Certain Condition of Loading. 造船協会々報 54 号（昭和 9 年) 121 163.

(16). G. Schnadel ; Über die Knickung von Platten. Jb. Schiffbt. Ges. Bd. 30 (1929) 170 $\sim 186$.

Die Überschreitung der Knickgrenze bei dünnen Platten. Verh. 3 int. Congreße f. techn. Mech. (1930) 73 81.

(17) Th. von Kármán, E. E. Sechler, L. H. Donnell : The Strength of Thin Plates in Compression. Trans. A. S. M. E. 54 (1932) 53〜 56.

（18）山本峰雄, 近藤一夫：圧縮を受ける矩形薄板のバックリングと破壊, 航空学会誌 2 巻（昭和 10 年） 323 336, 同上訂正, 同 2 巻 998 999.

(19) S: Timoshenko : Theory of Elastic Stability (1936) 390.

(20) K. Marguerre : Die mittragende Breite der gedrückten Platte. Luftfahrtforschung Bd. 14 (1937) $121 \sim 128$.

(21) K. Marguerre, E. Trefftz ; Über die Trägfäigkeit eines längs-belasteten Plattenstreifens nach Überschreiten der Beullast. Z. A. M, M. Bd. 17 (1937) 85 100.

(22) S. Timoshenko ; Über die Stabilität versteifter Platten. Eisenbau Bd. 12 (1921) 147 163.

(23) L. Rendulic ; Über die Stabilität von Stäben, welche aus einem mit Randwinkeln Verstärkten Blech bestehen. Ing. Arch. Bd. 3 (1932) 447 453.

(24) J. Miles ; Stability of Rectangular Plates Elastically Supported at the Edges. J. Appl. Mech. Vol. 3 (1936).

(25) E. Chwalla ; Die Stabilität eines elastisch gebetteten Druckstäbe. Z. A. M. M. Bd. 7 (1927) $276 \sim 284$.

(26) R. Barbré : Beulspannungen von Rechteckplatten mit Längssteifen bei gleichmäßiger Druckbeanspruchung. Bauing. Bd. 17 (1936) 268 273.

Stabilität gleichmäßig gedrückter Rechteckplatten mit Längs- oder Quer-Steifen. Ing. Arch. Bd. 8 (1937) 117 150.

(27) E. E. Lundquist, C. M. Fligg ; A Theory for Primary Failure of Straight Centrally Loaded Column. N. A. C. A. Tech. Rep. No. 582 (1937).

（28）倉西正塥：軸圧縮荷重を受くる薄肉平面壁「プロフィル」柱の壁面へし折れ強度（其の 1 ，其の 2， 其の 3 ) 航空学会誌 2 巻 (昭和 10 年) 55 86, 259 284, 485 506.

(29) W. L. Howland; Effect of Rivet Spacing on Stiffened Thin Sheet under Compression. J. Aero. Science Vol. 3 (1935 6) 434 439.

(30) A. Kromm ; Einfluß der Nietteilung auf die Druckfestigkeit versteiften Schalen aus Duralmin. Luftfahrtforschung Bd. 14 (1937) 116 120.

(31) E. E. Sechler : Stress Distribution in Stiffened Panels under Compression. J. Aero. Science Vol. 4 (1936 7) 320 323.

(32) J. R. Fischel : Effective Widths in Stiffened Panels under Compression. J. Aero. Science Vol. 7 (1940) 213 216.

(33) H. L. Cox ; Summary of the Present State of Knowledge Regarding Sheet Metal Construction. A. R. C., R. \& M. No. 1553.

(34) H. B. Dickinson, J. R. Fischel ; Measurement of Stiffener Stresses and Effective Widths in Stiffened Panels. J. Aero. Science Vol. 6 (1939) 249 254.

(35) G. F. Wallace ; Note on the Strength of Stressed Skin Fuselages. J. Roy. Aero. Soc. Vol. 40 (1936) 304 312.

(36) O. S. Heck, H. Ebner ; Formulae and Methods of Calculation of the Strength of the Plate and Shell Structures in Aeroplane. J. Roy. Aero. Soc. Vol. 40 (1936) 769 788.

(37) N. J. Hoff ; Instability of Monocoque Structures in Pure Bending. J. Roy. Aero. Soc. Vol. 42 (1938) 291 346.

(38) E. R. Reff ; Empirical Formulas for Allowable Compression Loads in Stiffened Sheet Panels. J. Aero. Science Vol. (1939) 505 510.

(39) H. L. Cox ; Stress Anălysis of Thin Metal Construction. J. Roy. Aero. Soc. Vol. 44 (1940) $231 \sim 272$.

(40) E. H. Mitchell : The Strength of Ship's Structure under Compressive Stresses. T. I. N. A. Vol. 78 (1936) $21 \sim 34$.

(41) R. V. Southwell : On the Analysis of Experimental Observations in Problems of El- 
astic Stability. Proc. Roy. Soc. London Ser. A. Vol. 135 (1932) 601

(42) L. H. Donnell : On the Application of Southwell's method for the Analysis of Buckling Tests. S. Timoshenko 60 th Aniversary Volume (1938) 27
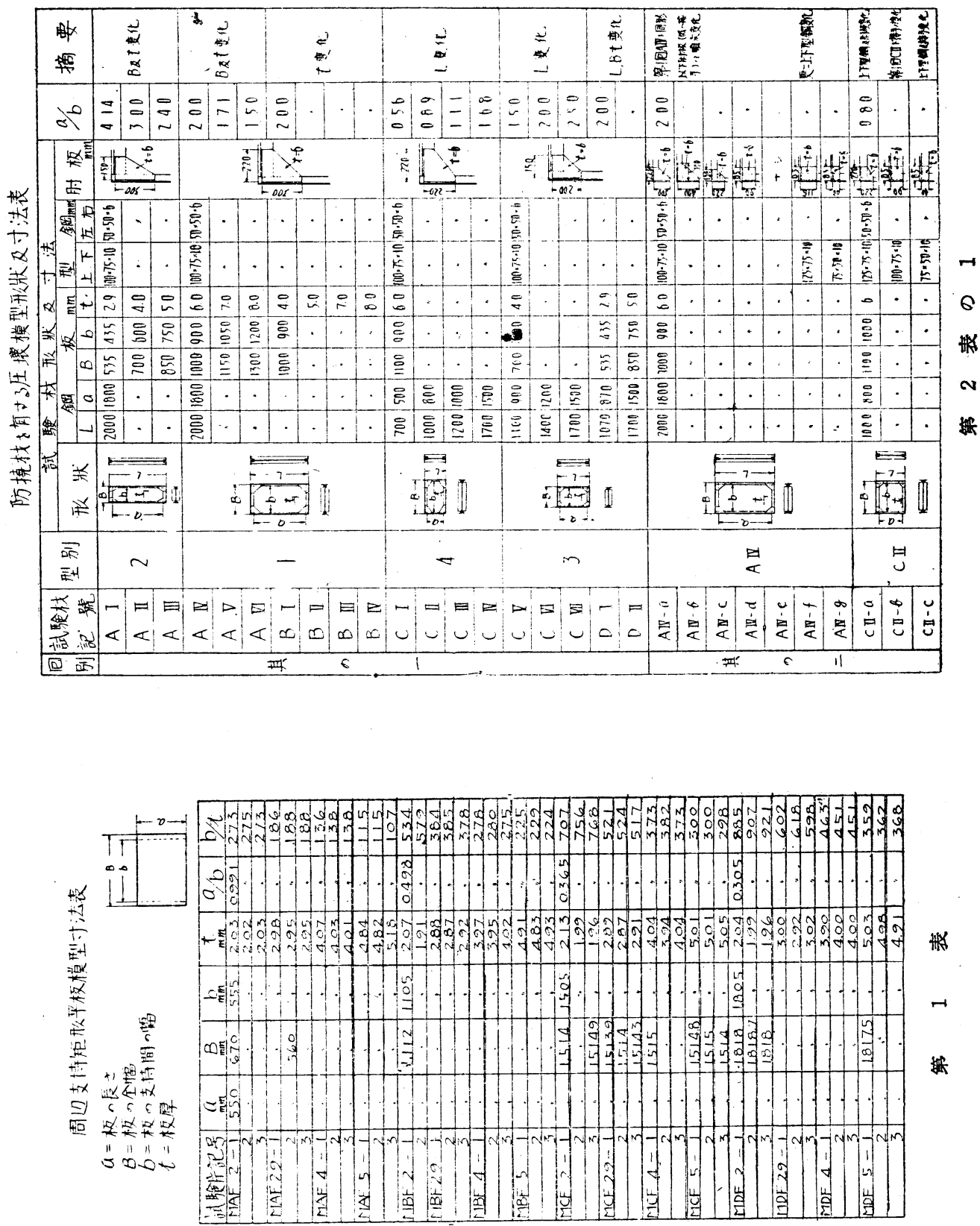


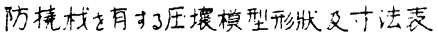

\begin{tabular}{|c|c|c|c|c|c|c|c|c|c|c|c|c|c|c|}
\hline \multirow[t]{2}{*}{ 问 } & \multirow{2}{*}{ 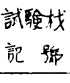 } & \multirow[b]{2}{*}{ 型别 } & \multirow{2}{*}{\multicolumn{10}{|c|}{ 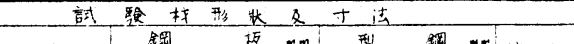 }} & \multirow[b]{2}{*}{$a / b$} & \multirow[b]{2}{*}{ 落 } \\
\hline & & & & & & & & & 型 & 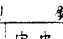 & $-\pi x$ & a. 接 & & \\
\hline & $A I-a$ & AI型 & tit & 2000 & 1200 & 1028 & 435 & 2.9 & $|\operatorname{man} 75 \times 15|$ & $500.58 \times 6$ & $6.50 .50 \times 6$ & 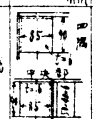 & 414 & 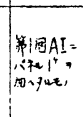 \\
\hline & E I & \multirow{4}{*}{ E型 } & \multirow{4}{*}{ 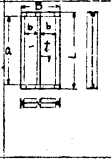 } & 2000 & 1900 & \multirow{4}{*}{1020} & \multirow{4}{*}{435} & \multirow{4}{*}{2.9} & \multirow{4}{*}{$75=50 \times 10$} & \multirow{4}{*}{50.51 .6} & \multirow{4}{*}{50.580 .6} & \multirow{4}{*}{ 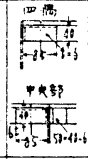 } & 437 & \multirow{4}{*}{ 扎交化 } \\
\hline & $E$ II & & & 1000 & 900 & & & & & & & & 207 & \\
\hline & E III & & & $\pi 5$ & 435 & & & & & & & & 100 & \\
\hline & E II & & & 300 & 200 & & & & & & & & 0.46 & \\
\hline & F I & \multirow{3}{*}{$F$ 型 } & \multirow{3}{*}{ a } & 2000 & 1900 & \multirow{3}{*}{1020} & \multirow{3}{*}{435} & \multirow{3}{*}{2.9} & \multirow{3}{*}{$75 \times 50 \times 10$} & \multirow{3}{*}{ 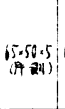 } & \multirow{3}{*}{ 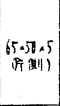 } & \multirow{3}{*}{$F_{85} \rightarrow \sqrt{156}$} & 4.77 & \multirow{3}{*}{ 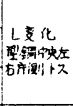 } \\
\hline 其 & $F \quad \mathbb{I}$ & & & 1000 & 900 & & & & & & & & 207 & \\
\hline & $F \quad \mathbb{I}$ & & & 535 & 135 & & & & & & & & 1.00 & \\
\hline & $G \quad I$ & \multirow{3}{*}{$G$ 型 } & \multirow{3}{*}{ 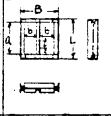 } & & & 1020 & & & & 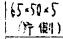 & & $\sqrt{19}$ & 207 & \\
\hline & $G \quad \mathbb{I}$ & & & 1000 & 900 & 1010 & 435 & 2.9 & $75 \cdot 50 \times 10$ & 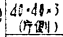 & $\{50.50 \times 6$ & 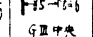 & 207 & 性中央 \\
\hline & $G \quad$ II & & & & & 1010 & & & & $\begin{array}{c}41.2 .9 \\
(+2)\end{array}$ & & 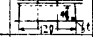 & 2.07 & \\
\hline 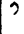 & $\begin{array}{ll}H & I\end{array}$ & & $=-8-$ & 1090 & 900 & 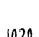 & 135 & 29 & & & & - & 2.07 & L彔 \\
\hline & $\begin{array}{ll}H & I\end{array}$ & ${ }^{2}$ & & 535 & 435 & 106 & 47 & 21 & (1) & 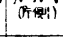 & (itani & $\prod_{t=6}^{110}$ & 1.00 & 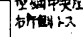 \\
\hline & I I & & & 1000 & 400 & 900 & 435 & 29 & $75500+1$ & & $1.40 \times 5$ & & 207 & Litut \\
\hline & $\begin{array}{ll}1 & \text { II } \\
\end{array}$ & & thy & 515 & 435 & 990 & $4 / 1$ & 21 & Tho & $07+(14)$ & 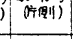 & $L_{15}+t^{-6}$ & 100 & 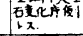 \\
\hline$\equiv$ & $J$ & & 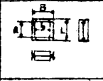 & 535 & 435 & 535 & 435 & 6 & $75.50 \times 10$ & $+v$ & 65.50 .5 & & 1.00 & 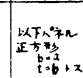 \\
\hline & J & & $\frac{\sqrt{B}}{\Theta}$ & 535 & 435 & 575 & 435 & 6 & $75 \times 51.110$ & $+z$ & $\begin{array}{r}\pi \times 5 \times 40 \\
0+(14) \\
\end{array}$ & & 1.00 & 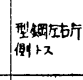 \\
\hline & $\mathrm{J} \cdot \mathbf{I I}$ & & a & 575 & 435 & 575 & 435 & 6 & $75558 \times 10$ & $+:$ & 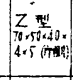 & $F 5+\frac{100}{100}$ & 1.00 & 1上 \\
\hline & $\mathrm{J}$ '位 & & 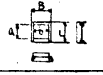 & 535 & 435 & 515 & 435 & 6 & $75 \times 55 \times 10$ & +3 & 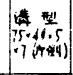 & & 1.60 & 人上 \\
\hline & $\begin{array}{ll}K & I\end{array}$ & & 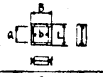 & 535 & 435 & 535 & 435 & 6 & $|75 \times 50 \times 10|$ & $+:$ & $50-50.6$ & & 1.00 & \\
\hline & $K \mathbb{I}$ & & 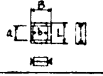 & 535 & 435 & 535 & 435 & 6 & $\mid 80.50 \times 6$ & $+i$ & $50.50 \times 6$ & $6 \longdiv { 1 5 - 6 }$ & 100 & 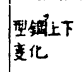 \\
\hline & $K \mathbb{I}$ & 1.1 & 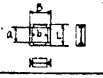 & 515 & 435 & 515 & 435 & 6 & $40 \times 4065$ & $+i$ & $40 \times 40 \times 5\}$ & $\sqrt{3}$ & 1.00 & 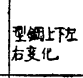 \\
\hline & $K \mathbb{I}$ & & 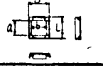 & 515 & 435 & 575 & 435 & 6 & $\left|\begin{array}{l}40 \times 40 \times 5 \\
0+(8,1)\end{array}\right|$ & $T=$ & 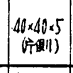 & & 1.00 & 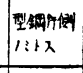 \\
\hline & A I & & 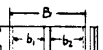 & & & & $0,=514$ & & & $38 \times 30 \times 8$ & & & $a_{b}=107$ & \\
\hline & $A \mathbb{I}$ & & -4 & & 330 & $\pi / 2$ & $b_{2}=55$ & 4 & & $38 \times 30.3$ & & & $a \frac{a}{a}=299$ & 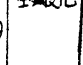 \\
\hline
\end{tabular}

第 2 表 の 2 

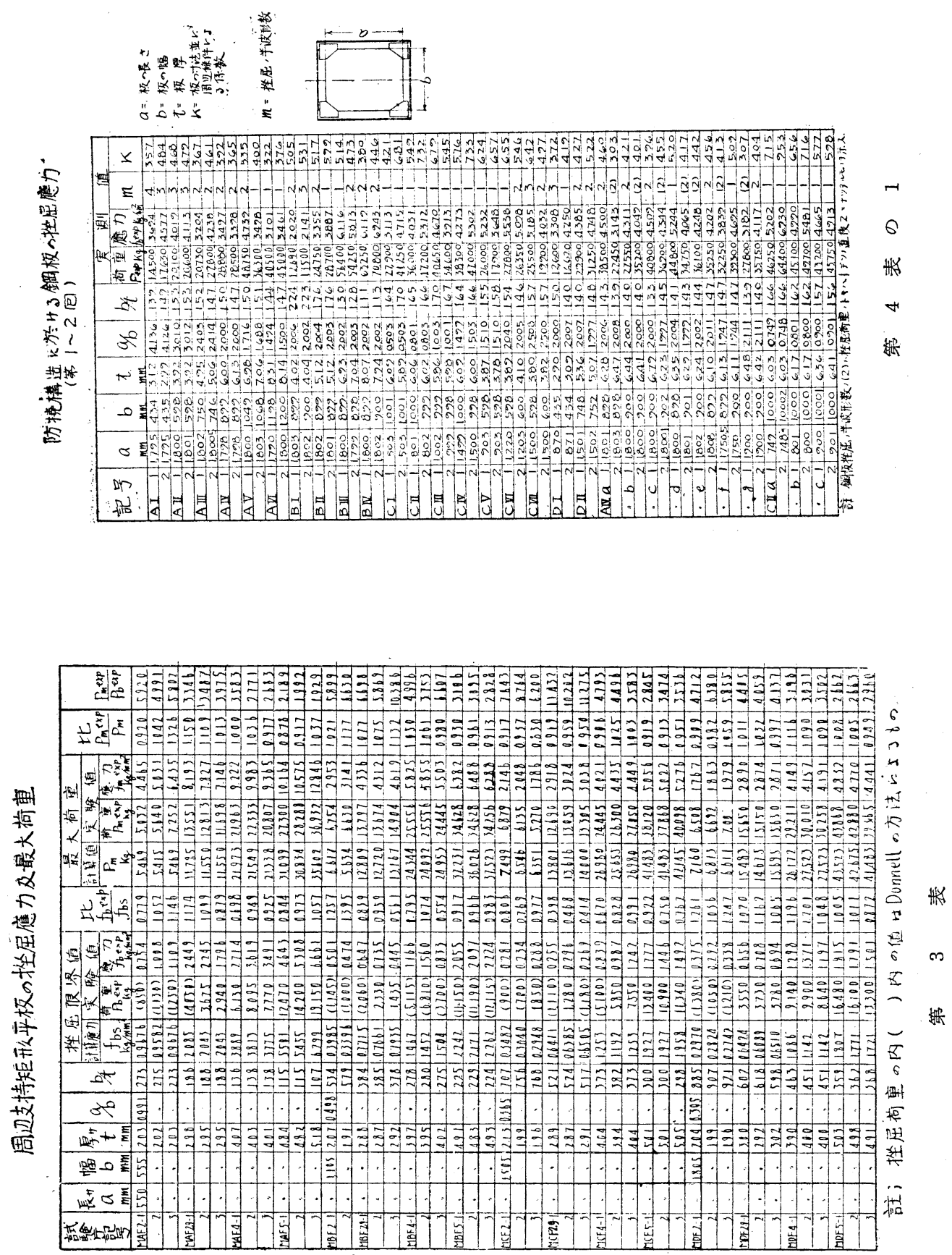

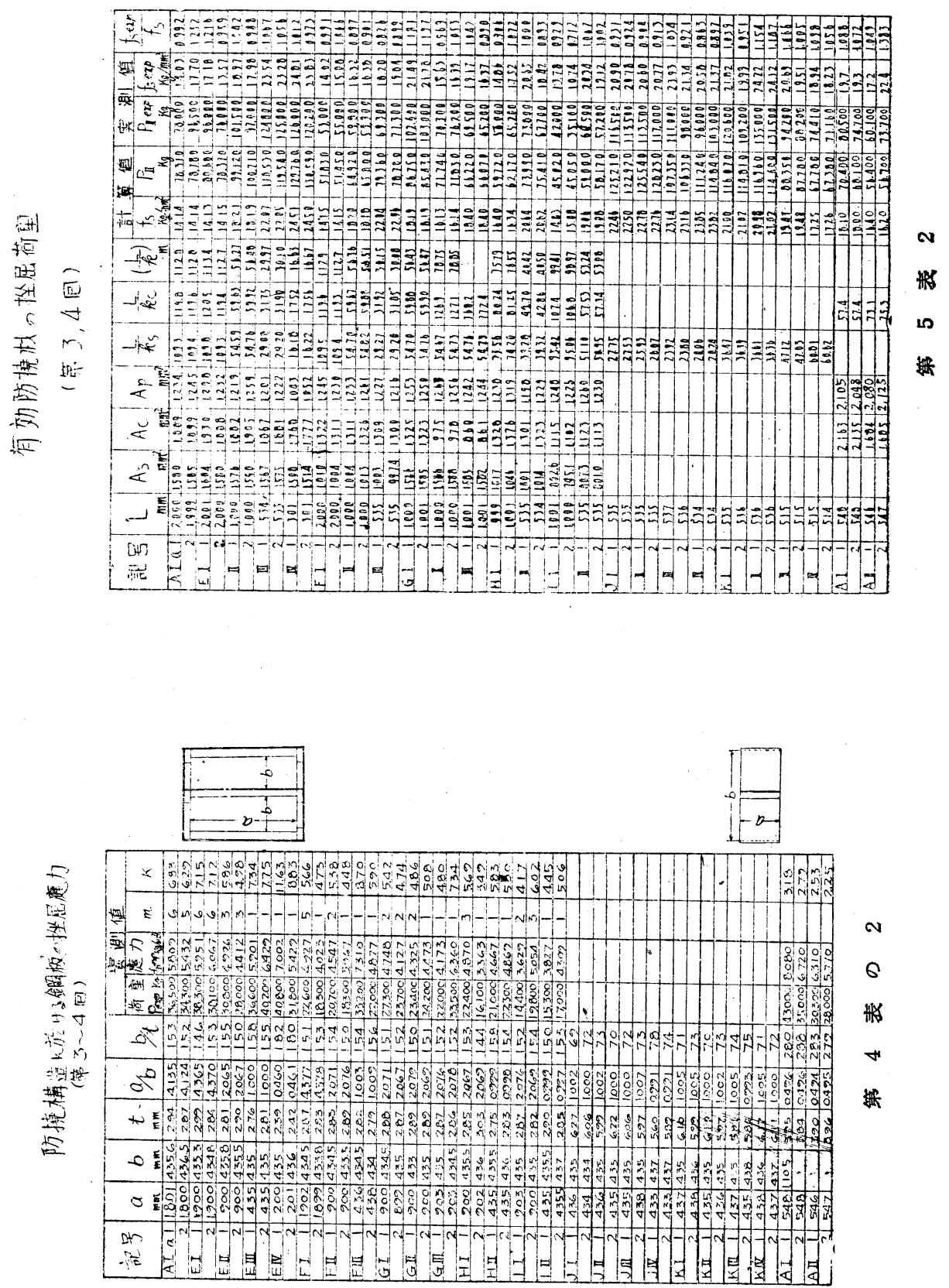


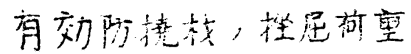

$$
\text { (寒 1，2它) }
$$

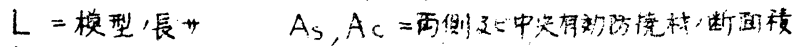

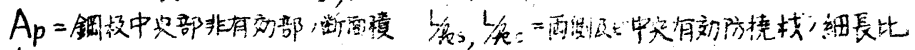

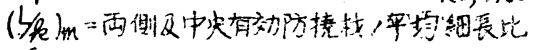

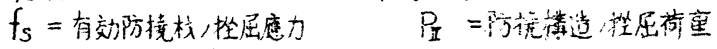

\begin{tabular}{|c|c|c|c|c|c|c|c|c|c|c|}
\hline $\begin{array}{l}\text { 記 } \\
\text { 号 }\end{array}$ & $L_{m m i}$ & As & $A_{c}$ & $A_{p}$ & $\frac{L}{k s}$ & $\frac{L}{k c}$ & ( & $\frac{\bar{t}^{2}}{f_{S}}$ & 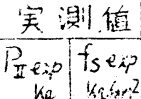 & $\frac{f_{\text {sexp }}}{f_{s}}$ \\
\hline n! & & & & & & & & & & \\
\hline II & $\frac{19}{2,00}$ & & & & 117.9 & & & $\begin{array}{l}1.322 \\
1400 \\
182760\end{array}$ & 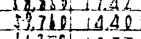 & $\frac{22.21}{1.029}$ \\
\hline II & 2000 & & & & & & & 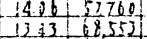 & \begin{tabular}{|c|c|c|c|}
6,250 \\
62100 & 15 \\
\end{tabular} & \\
\hline II & $\frac{2600}{2000}$ & 32 & & & $\begin{array}{l}1275 \\
136.9\end{array}$ & & & 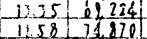 & $\left.\frac{7285}{74,159}\right]$ & {$\left[\begin{array}{l}0.5 \\
104\end{array}\right.$} \\
\hline $\bar{y}$ & $\frac{2200}{2000}$ & 3,308 & & & & & & -1150.75136 & 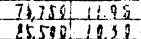 & $\frac{042}{1019}$ \\
\hline XII & 2000.2 & & & & & & & $\frac{9}{9} 97+329$ & $\frac{72810}{8}$ & 0.888 \\
\hline & 200 & & & & & & & & 1680 & a. 19 \\
\hline$B$ & & & & & & & & 1,44 & 81 & \\
\hline II & $\frac{2003}{200}$ & $\frac{2536}{2536}$ & & & 34.9 & & & 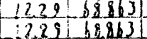 & $\frac{31230}{121450}$ & $\frac{1180}{3.972}$ \\
\hline III & - & 3.03 & & III & $\frac{14.5}{14.5}$ & & & 10.1962895 & 110811.94 & 186 \\
\hline II & 300 & $\frac{2601}{3,346}$ & & $=1,62$ & $\frac{192}{144.4}$ & & & 104485232 & 298,351124 & 1092 \\
\hline CI & 2000 & & & 3.84 & 18 & & & $\frac{-12.40}{1210}+\frac{92667}{146210}$ & 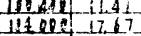 & \\
\hline$\pi$ & 70 & & & $\frac{2.94}{373}$ & 499 & & & $19,15 \mid 141.030$ & 10160 & 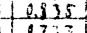 \\
\hline-1 & 60 & te & & 369 & $\frac{70}{78}$ & & & 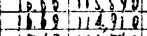 & 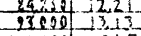 & $\frac{7}{139}$ \\
\hline II & $\frac{120}{120}$ & 885 & & 298 & & & & $\frac{1548}{1591569}$ & $(193,40.9$ & \\
\hline III & 1,70 & & & $\frac{3}{3.04}$ & 1113 & & & 14.019380 & $81260-118$ & 1845 \\
\hline$\pi$ & 1101 & 1,90 & & $\frac{219}{115}$ & $\frac{1186}{163}$ & -8 & -1 & $7730+72.500$ & 67600 & E? \\
\hline III & 1400 & 19. & & 1.06 & 1 & & & 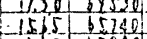 & 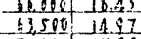 & I \\
\hline II & $\frac{1581}{700}$ & & & 1.13 & $\frac{8.4}{99.8}$ & & & 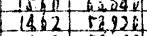 & $\frac{7330}{1690-10.1}$ & \\
\hline D:I & 1070 & $\frac{189}{153}$ & & $\frac{1,14}{3}$ & $\begin{array}{r}991 \\
-59.5 \\
5\end{array}$ & & & $\frac{1}{14.59}-5$ & $2 \sqrt{3}$ & \\
\hline I & $\frac{1.75}{1.699}$ & 23199 & & $\frac{67}{28}$ & $\begin{array}{l}58.9 \\
10.4\end{array}$ & & & $\begin{array}{r}1789 \\
1425\end{array}-60900$ & $\frac{8509}{1080}-\frac{180}{1644}$ & is \\
\hline$A \cdot \pi A$ & $\frac{1700}{2000}$ & $\frac{2335}{2873}$ & & $\frac{198}{282}$ & $\frac{108.6}{138}$ & & & $\frac{1425}{1140}: \frac{7460}{716,616}$ & 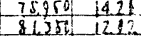 & is \\
\hline & & 205 & & 290 & .136 .6 & & & $1130.78,44$ & & \\
\hline 6 & $-2,001$ & $\frac{2880}{2897}$ & & -289 & $\frac{138.8}{18.7}$ & & & \begin{tabular}{|l|l|l|l|l|l|}
1.29 & 783 \\
\end{tabular} & $\begin{array}{l}77.189 \\
79.901 \\
1175\end{array}$ & $\frac{1918}{1,41}$ \\
\hline$c$ & $\frac{2000}{2000}$ & $\frac{2926}{2845}$ & & $\frac{185}{281}$ & $\frac{1319}{1379}$ & & & \begin{tabular}{|c|c|c|}
11107 & 856 \\
1141 & 7646
\end{tabular} & $\frac{8659}{8650} \frac{1123}{1230}$ & $\frac{1823}{i 13 !}$ \\
\hline$d$ & -2002 & $\frac{2.875}{2.878}$ & & $\frac{295}{298}$ & 4138.5 & & & $\frac{1433}{11362}$ & 67350 \$11 & 1891 \\
\hline 1 & 1019 & 284.5 & & 280 & 1379 & & & $120398,27,5$ & 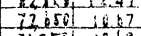 & 2.8 \\
\hline 7 & $\frac{2011}{2.691}$ & $\frac{2805}{2819}$ & & $\frac{\frac{3 \pi 4}{2} 25}{2.25}$ & $\frac{1324}{1225}$ & & & 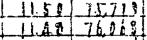 & 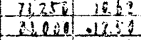 & $\frac{3}{19}$ \\
\hline & 2880 & 2.69 & & 2.75 & 4137.4 & & & $\frac{11.5 ! 75}{1.9+75}$ & & \\
\hline-8 & $\frac{2000}{2.590}$ & 2.894 & & $-\frac{4,43}{2,13}$ & 138.3 & & & $\frac{1.28}{11.29}+1,30$ & 12551221 & 1131 \\
\hline CII a & $\frac{1001}{1.00}$ & $\frac{2.036}{2.938}$ & & & 70.2 & & & $-\frac{186}{3} 117120$ & 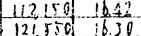 & $\frac{296}{9893}$ \\
\hline 6 & 100 & 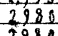 & & 3.8 & 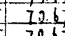 & - & & $\frac{163}{1111450}$ & 1011501808 & 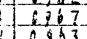 \\
\hline .c & $\frac{58}{28}$ & 30.3 & & $\frac{3.18}{3}$ & 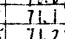 & & & 58 & $\frac{1919}{1963}$ & 19 \\
\hline
\end{tabular}

第 5 表 の 1 


\section{有効防撓栈。最大荷重 \\ (第1，2 包）}

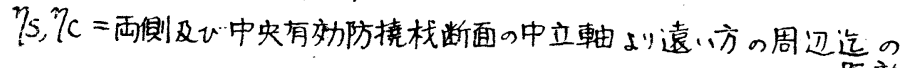

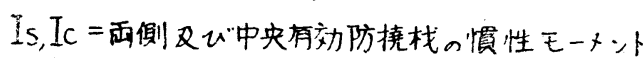

距離 $P_{C / A C}=$ 中央有効防摬栈的最大荷重 $P_{m}=$ 防㜔構造最大荷重

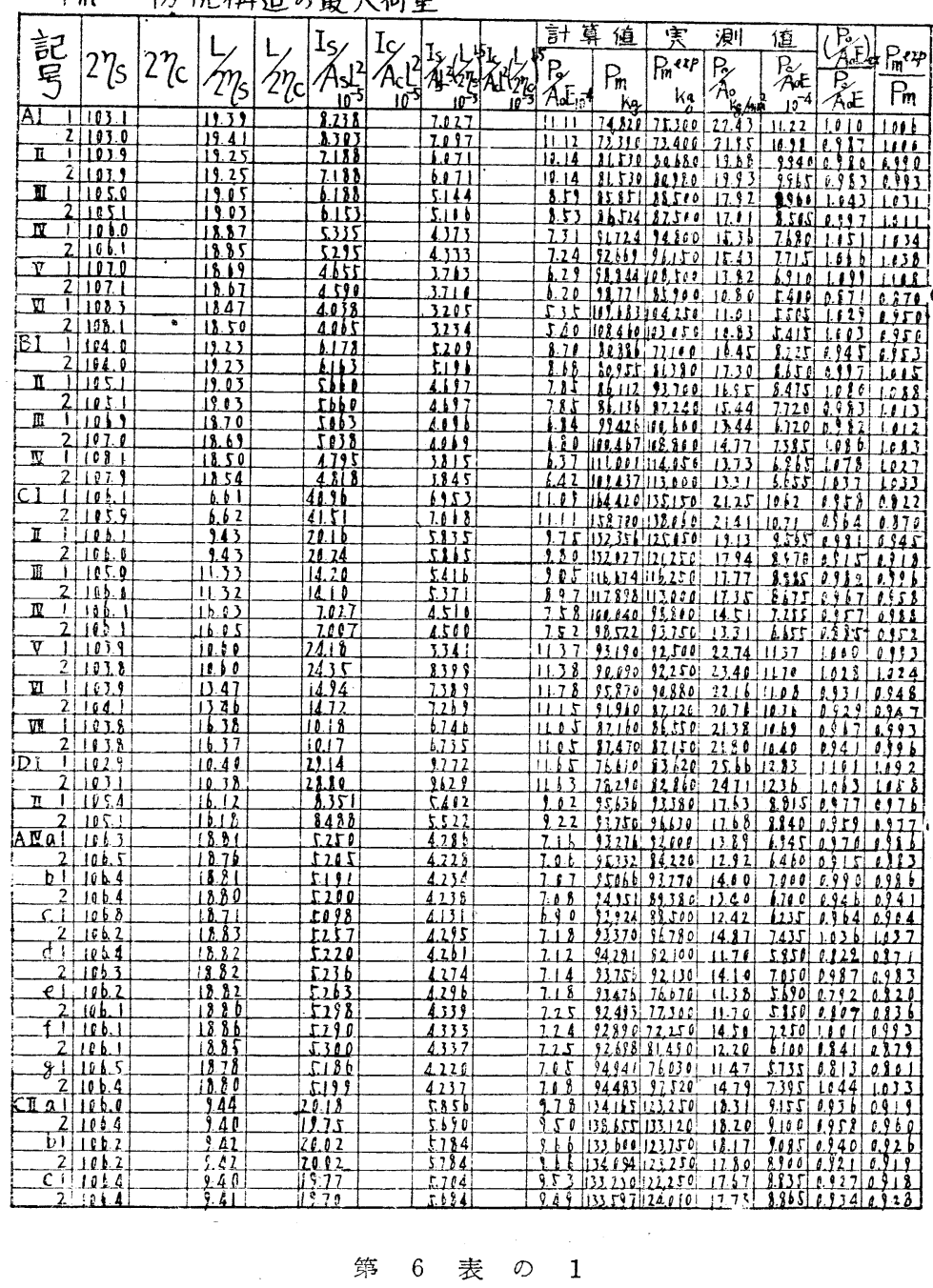




\section{有効防撓栰の最大荷重}

(第3，4同）

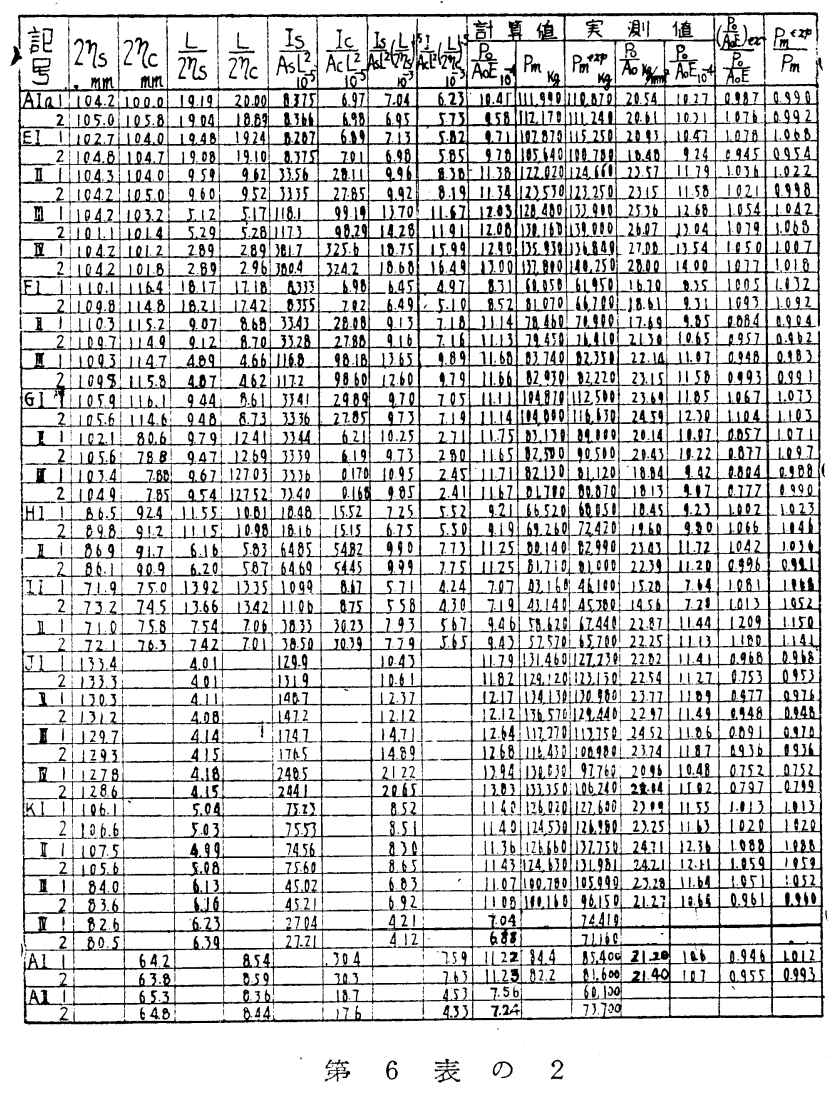

